\title{
GLOBALIZAÇÃO FINANCEIRA, CRASHES BOLSISTAS E CONTÁGIO: REVISÃO DE LITERATURA
}

\author{
FINANCIAL GLOBALIZATION, STOCK MARKET CRASHES AND FINANCIAL \\ CONTAGION: A LITERATURE REVIEW \\ GLOBALIZACION FINANCIERA, DESPLOMES DE LAS BOLSAS E CONTAGIO \\ FINANCIERO: UNA REVISON DE LITERATURA
}

\author{
Vítor Manuel de Sousa Gabriel (vigab@ipg.pt) \\ José Ramos Pires Manso (pmanso@ubi.pt)**
}

\begin{abstract}
RESUMO
Recorrendo a um trabalho de revisão bibliográfica e de análise de dados financeiros, no presente estudo abordamos a temática da globalização dos mercados financeiros e das suas causas, são analisadas as especificidades dos principais crashes bolsistas históricos: o de 1929, o de 1987, o das empresas tecnológicas e o da atual crise financeira global. De seguida, é estudada a temática do contágio ou propagação de crises entre mercados bolsistas, começando por analisar o seu conceito, para depois serem abordados os três principais canais de transmissão de crises, designadamente o comercial, o financeiro e o puro.

O fenómeno da globalização financeira ajudou à aproximação dos mercados financeiros, mas igualmente à criação de condições propicias à ocorrência de situações de contágio à escala global, penalizadoras da estabilidade económico financeira global, o que abre espaço à necessidade de repensar a arquitetura do sistema financeiro internacional.
\end{abstract}

Palavras-chave: globalização financeira, crashes bolsistas, contágio.

\begin{abstract}
Developing a literature review and an analysis of financial data, in this study we address the issue of globalization of financial markets and their causes and we analyze the specifics of the major stock market crashes. Then, we address the issue of contagion and spillovers across stock markets, analyzing concepts and the main transmission channels (commercial, financial and pure channels).

Financial globalization helps to explain the closeness of financial markets, but also to create propitious conditions for worldwide contagion, penalizing the global financial economic stability, which makes the need to rethink the international financial system architecture.
\end{abstract}

Keywords: Financial Globalization, stock market crashes, contagion.

\section{RESUMEN}

En este estudio se aplica una metodología de revisión de literatura y de análisis de datos financieros, para estudiar el tema de la globalización de los mercados financieros y de los principales desplomes bursátiles. Además, se estudia el tema del contagio financiero, comenzando con el análisis de su concepto, a 


\section{Eqitania \\ $\mathrm{s}$ c i e $\Omega$ c i a}

continuación son analizados los tres principales canales de transmisión de las crisis financieras (comercial, financiero y puro).

El fenómeno de la globalización financiera ayudó a la aproximación de los mercados financieros, pero también ayudó a crear condiciones propicias para la ocurrencia de situaciones de contagio en todo el mundo, penalizando la estabilidad económica y financiera mundial, que hace lugar a la necesidad de repensar la arquitectura del sistema financiero internacional.

Palabras-llave: Globalización financiera, desplomes de las bolsas, contagio financiero.

* UDI - Unidade de Investigação para o Desenvolvimento do Interior, Instituto Politécnico da Guarda

**NECE - Núcleo de Estudos em Ciências Empresariais, Universidade da Beira Interior. 


\section{Egitania \\ $s$ c i e $\Omega$ c i a}

\section{INTRODUÇÃO}

O crescimento do comércio mundial, a integração económica entre países e a integração dos mercados financeiros criaram novas oportunidades de investimento e de diversificação do mesmo, geraram uma maior interdependência entre os principais mercados financeiros mundiais e contribuíram para o reforço das ligações entre estes, mas ao mesmo tempo proporcionaram condições facilitadoras da ocorrência de contágio e de propagação de crises, em especial em contexto de queda acentuada dos mercados bolsistas.

O processo de globalização financeira em curso tem sido acompanhado por um aumento de instabilidade dos mercados financeiros e pelo aparecimento de crises financeiras com impacto à escala global. De acordo com Stiglitz (1999), as crises financeiras ocorridas desde finais da década de 1980 mostraram que a desregulamentação e a liberalização dos mercados não produziriam as consequências esperadas, devido às imperfeições de mercado. A livre entrada e saída de recursos financeiros nos mercados financeiros deixou-os mais expostos $e$ vulneráveis a crises. Até ao início da década de 1980, as crises eram acontecimentos individuais e localizados nos mercados individualizados, mas a partir do crash de 1987 elas passaram a ser globais, fruto da interação e da interdependência entre os mercados dos diversos países. O crash bolsista de 1987, a invasão do Kuwait, em 1990, o ataque terrorista às torres gémeas nos EUA, em 2001, e a emergência da Crise Financeira Global provocaram reações globais nos mercados, tendo a eficácia das estratégias de diversificação internacional sido prejudicada.

O presente trabalho tem como objetivo a análise das causas e consequências dos principais episódios de crise bolsista, dando especial ênfase ao recente episódio da crise financeira global, ocorrido no epicentro do sistema financeiro internacional. De modo a concretizar o objetivo de investigação, recorre-se fundamentalmente a um trabalho de revisão bibliográfica, mas também à análise gráfica do comportamento de séries bolsistas.

O trabalho desenvolvido está estruturado do seguinte modo: a parte 2 aborda a temática da globalização dos mercados financeiros e das suas causas; na parte 3 são apresentados os principais crashes bolsistas históricos, desde a Grande Depressão até à atual crise financeira global; na parte 4 é abordada a temática do contágio de crises entre mercados bolsistas, desde o seu conceito até aos mecanismos de transmissão; na parte 5 será desenvolvida uma análise reflexiva acerca do sistema financeiro internacional, enquanto na parte 6 são expostas as principais conclusões.

\section{GLOBALIZAÇÃO DOS MERCADOS FINANCEIROS}

Após a segunda Guerra Mundial assistiu-se a um elevado ritmo de crescimento do comércio mundial, claramente superior ao ritmo de crescimento da produção. Neste contexto de crescimento, a multinacionalização das empresas tornou-se uma realidade. Desde a década de 1960, as empresas com vocação internacional começaram a procurar formas de ultrapassar 


\section{Egitania}

$s$ c i e $\Omega$ c i a

as dificuldades encontradas a nível nacional, designadamente as de natureza regulamentaria e monetária. Algumas dessas empresas adotaram estratégias globais, desenhadas em função do mercado global e das características específicas de cada mercado.

A par da multinacionalização de algumas empresas, ocorreu um processo de liberalização dos movimentos de capitais, favorecido pelo crescimento do mercado dos eurodólares e das eurodivisas (Boyer, 1997)1․ Em 1974, os EUA eliminaram as barreiras à saída de capitais, impostas na década anterior, e outros países seguiram o mesmo exemplo, o que fez com que, progressivamente, as barreiras impeditivas à livre circulação de fluxos monetários e financeiros viessem a ser abolidas, dando assim origem à globalização dos mercados financeiros. A globalização destes mercados traduziu-se, portanto, na integração dos mercados financeiros nacionais de todo o mundo num mercado financeiro internacional e globalizado (Fabozzi, 1995).

Segundo Fabozzi (1995), foram três os principais fatores que contribuíram para a globalização financeira: os desenvolvimentos tecnológicos, a institucionalização dos mercados e a liberalização financeira.

As alterações tecnológicas, ocorridas em especial na informática e nas telecomunicações, permitem ligar os agentes de mercado em qualquer parte do mundo, transmitindo informação em tempo real e executando ordens de investimento quase instantaneamente. Com estas alterações, o sistema financeiro aperfeiçoou a sua capacidade de recolha de informação relevante para o investimento (Putman e Zimmer, 1987). A disponibilidade de informação barata contribuiu, por um lado, para melhorar a capacidade do mercado na avaliação dos riscos e, por outro, para aumentar a eficiência e a liquidez dos mercados globais (Strange, 1990; Modigliani e Perotti, 1991; Williams; 1993; Fabozzi, 1995).

A institucionalização dos mercados é outro dos fatores que, segundo Fabozzi (1995), terá contribuído para o processo de globalização financeira. A institucionalização está fortemente ligada à gestão coletiva da poupança e de ativos financeiros de particulares. Esta gestão é cada vez mais exercida por investidores institucionais, como as companhias de seguros, os fundos de pensões e as sociedades de investimento ou de fundos mútuos (Plihon, 2007). Ao contrário de muitos investidores individuais, estes investidores "globais" não limitam o seu investimento ao mercado nacional de origem, mas procuram oportunidades de investimento à escala global, numa tentativa de maximizar a rendibilidade e de diversificar os seus investimentos. Para implementarem as suas estratégias de investimento, os investidores institucionais dispõem de complexos sistemas de gestão de risco e de um elevado grau de especialização.

Outro fator que contribuiu para a globalização financeira foi o da liberalização dos mercados financeiros. As últimas décadas foram caraterizadas por alterações significativas ao nível do funcionamento dos mercados financeiros internacionais. Os empréstimos concedidos por bancos privados internacionais sofreram um aumento significativo e diminuiu o peso do Fundo

\footnotetext{
1 Tendo sido criados em finais da década de 1950, estes mercados envolviam depósitos em moedas convertíveis, efetuados em instituições financeiras, sediadas fora do país da moeda de origem. Em 1958, foi criado um offshore em Londres, um mercado interbancário de capitais, denominado em dólares, sendo esse o motivo porque surgiu a palavra eurodólar, e que viria a conhecer um significativo crescimento na Europa.
} 
Monetário Internacional (FMI) neste tipo de operações². Esta alteração terá criado condições à flexibilização das regulamentações financeiras nacionais (Putman e Zimmer, 1987).

Segundo Helleiner (1995) e Putman e Zimmer (1987), a criação de mercados fora das fronteiras do país de origem, como foi o euromercado, relativamente aos investidores norte-americanos, levou a que os governos reconsiderassem as suas regulamentações mais rígidas e também as formas de gestão das instituições. Os governos não incentivaram, por vontade própria, o processo de liberalização financeira, limitando-se a reagir às alterações ocorridas a nível global. Neste quadro de liberalização, destaca-se a abolição da regulamentação de câmbios, que facilitou a circulação internacional do capital, em particular a abertura do sistema financeiro japonês, em meados da década de 1980, e a eliminação dos sistemas europeus de controlo de câmbios, com a criação do mercado único.

A figura 1, inspirada em Kaminsky e Schmukler (2008), apresenta a evolução dos índices de liberalização financeira, referentes a mercados maduros e a mercados emergentes ${ }^{3}$, devendo ler-se da seguinte forma: o valor 3 na ordenada significa fechado, o 2 significa parcialmente liberalizado e o 1 significa totalmente liberalizado. Um país é considerado completamente liberalizado quando pelo menos dois setores estão completamente liberalizados e o terceiro está parcialmente liberalizado. Um país é considerado parcialmente liberalizado se pelo menos dois setores estiverem parcialmente liberalizados.

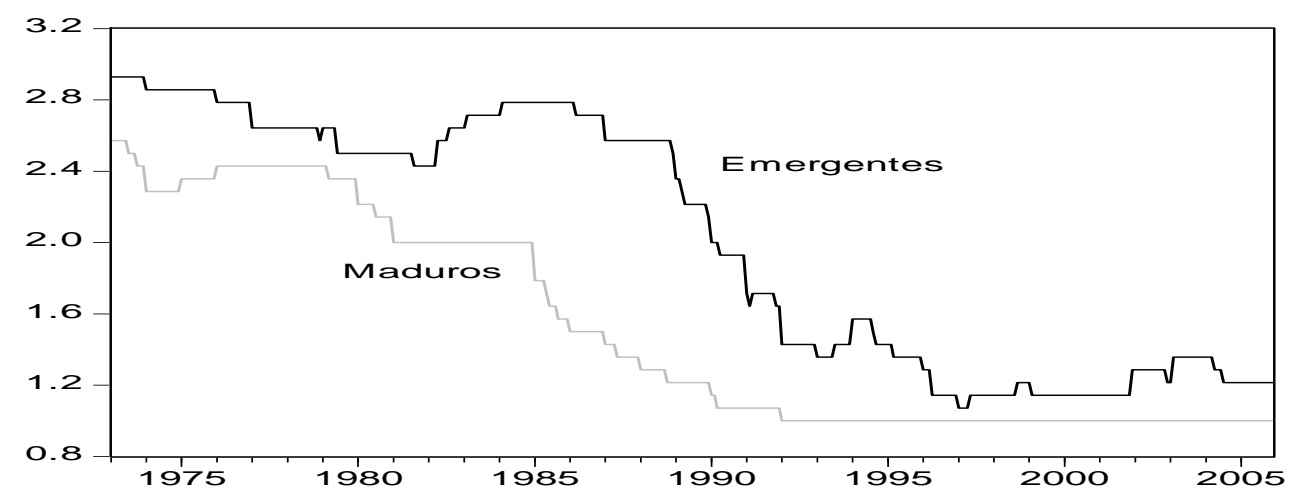

Figura 1: Índice de liberalização financeira

Notas: Os índices de liberalização incluem a liberalização da conta de capital, do setor financeiro doméstico e do mercado bolsista, no período compreendido entre janeiro de 1973 e dezembro de 2005. Esta figura foi elaborada a partir de Kaminsky e Schmukler (2008).

2 Por outro lado, os utilizadores do crédito também mudaram. Após a $2^{\text {a }}$ Guerra Mundial, os principais recetores de empréstimos eram os países europeus, para fazer face ao esforço de reconstrução. A partir da década de 1970, os países em desenvolvimento passaram a ser os principais utilizadores.

$3 \bigcirc$ grupo dos mercados maduros inclui: Alemanha, Canadá, Dinamarca, Espanha, Finlândia, França, Irlanda, Itália, Japão, Noruega, Portugal, Reino Unido, Suécia e EUA. O grupo dos mercados emergentes inclui: Argentina, Brasil, Chile, Colômbia, Hong-Kong, Indonésia, Coreia do Sul, Malásia, México, Peru, Filipinas, Taiwan, Tailândia e Venezuela. 
Da análise da figura 1 conclui-se que os processos de liberalização destes dois tipos de mercados seguiram percursos diferentes. Enquanto nas economias maduras o processo de liberalização aconteceu de forma ininterrupta, nas economias emergentes ele fez-se com algumas intermitências.

Até ao final da segunda guerra mundial, o mercado financeiro inglês era o mais importante a nível internacional, sendo substituído, desde então, pelo mercado dos EUA. Por outro lado, o dólar substituiu a libra como moeda de referência internacional e tornou-se ele próprio essa referência no investimento e no comércio internacionais. Mais tarde, foram criados centros financeiros importantes noutros países, como são os casos do alemão e do japonês, entre outros.

A liberalização também chegaria aos mercados bolsistas. A bolsa de Londres foi a primeira a iniciar um processo de desregulamentação, em 1986, com a abertura deste mercado a instituições financeiras estrangeiras e a criação de condições tendentes a aumentar o nível de concorrência, especialmente em matéria de comissões, por serviços prestados.

O processo de globalização passou por três fases (Chesnais, 1998): a primeira, compreendida entre 1960 e 1980, caraterizou-se por sistemas monetários nacionais fechados, com a internacionalização financeira restringida ao sistema dos eurodólares. A segunda, que decorreu entre 1980 e 1985, envolveu a desregulamentação financeira e a securitização da dívida ${ }^{4}$ (especialmente no mercado de obrigações). A terceira, e última, iniciou-se em meados da década de 1980, com uma maior abertura dos mercados domésticos e com a entrada dos mercados emergentes no processo de globalização. A recessão ocorrida no início da década de 1990, que envolveu diversas economias desenvolvidas, deu origem à transferência de capitais para os mercados emergentes e contribuiu para reforçar a integração destes mercados no processo de globalização.

Na figura 2 é apresentada a evolução quinquenal do investimento direto estrangeiro (IDE) líquido, de 1970 a 2010, a partir de informação reunida pelo Banco Mundial, em 2013, mostrando, claramente, um aumento significativo deste, sobretudo a partir da década de 1990, quer para o conjunto dos países desenvolvidos quer para o dos países em desenvolvimento.

4 Securitização da dívida é uma prática financeira que consiste em agrupar vários tipos de passivos financeiros, convertendo-os em títulos negociáveis no mercado de capitais. Deste modo, a dívida é vendida, na forma de títulos, para vários investidores (Bancos, Fundos de Investimento, etc.), como forma de rentabilizar o capital investido, cabendo ao comprador do título securitizado a cobrança individual de todas as dívidas que compõem o título. 


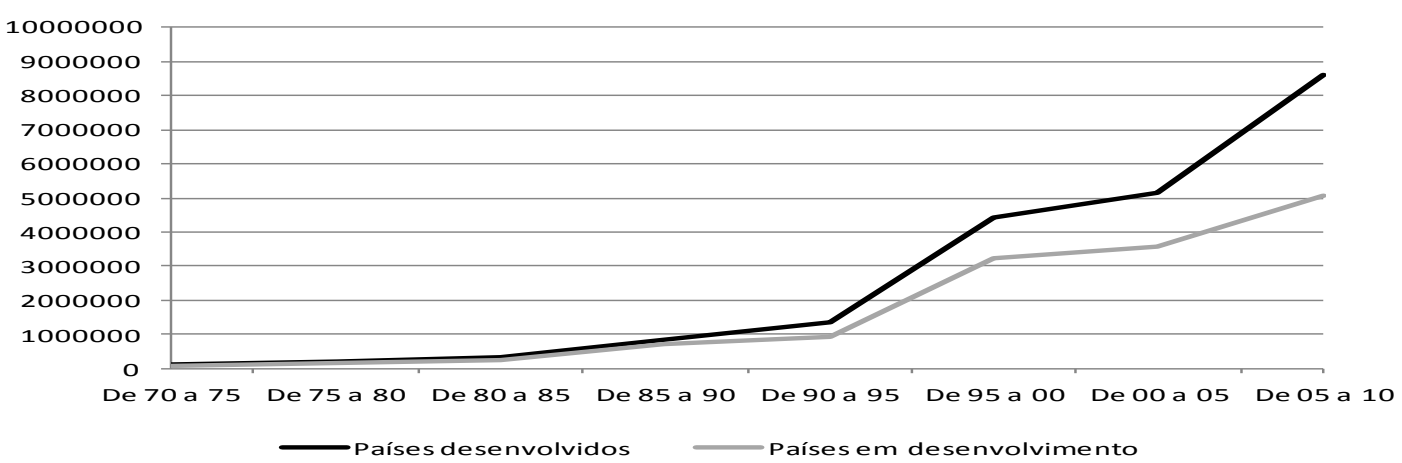

Figura 2: Evolução quinquenal do IDE em países desenvolvidos e em países em desenvolvimento (biliões USA\$)

Fonte: Banco Mundial. A partir de informação disponível em http://data.worldbank.org/.

A tabela 1, elaborada a partir de informação disponibilizada pelo Banco Mundial, em 2013, ilustra a importância relativa de alguns dos principais mercados internacionais de valores, através da capitalização bolsista (entendida esta como o valor dos ativos financeiros suscetíveis de negociação) e da relação entre esta e o Produto Interno Bruto (PIB) de cada país. Ao longo do período considerado, o mercado dos EUA apresentou um nível de capitalização muito superior ao dos restantes mercados.

Em 2010, a capitalização bolsista dos EUA representa 31\% da capitalização mundial, sendo quatro vezes superior à do mercado japonês, o segundo em termos de capitalização. Face ao ano de 1990, todos os mercados analisados viram aumentar os valores das suas capitalizações bolsistas. A nível mundial, o valor da capitalização bolsista foi superior a 90\% do PIB.

A tabela 2 elaborada a partir de informação disponibilizada pelo Banco Mundial, em 2013, apresenta o rácio entre o valor das ações negociadas e o PIB de cada país ou mercado. HongKong evidencia-se com o rácio mais elevado (superior a 700\%), seguem-se os EUA, com o valor das ações negociadas a representar o dobro do valor do PIB (200\%), e o Reino Unido com 133\%. Nos restantes países analisados, o valor das ações negociadas foi inferior ao do respetivo PIB. Em termos mundiais, apesar das fortes quedas sofridas nas cotações bolsistas, em consequência da recente crise financeira, o valor das ações negociadas supera o valor do PIB mundial, o que atesta bem a importância dos mercados bolsistas no contexto financeiro internacional.

\section{ANÁLISE DOS PRINCIPAIS CRASHES BOLSISTAS}

A história dos mercados financeiros é caraterizada por fases de subidas eufóricas e por fases de quedas significativas nos índices bolsistas. As quedas mais acentuadas são a de 1929, a de 1987, a de 2000 e a da crise de 2007 em diante. Em qualquer destes casos, as quedas começaram na praça financeira norte-americana e chegaram às restantes praças financeiras mundiais, seguindo um processo de propagação em série. Estas quedas foram de tal forma acentuadas e extensivas à escala global que alguns autores as passaram a designar por crashes ou quedas globais. De acordo com Stiglitz (1999), a frequência com que as crises 
financeiras têm ocorrido, em especial a partir da década de 1980, mostrou que a desregulamentação e a liberalização dos mercados não produziriam as consequências esperadas, em consequência de imperfeições de mercado. A livre entrada e saída de recursos financeiros nos mercados financeiros deixa-os mais expostos e vulneráveis às crises.

\begin{tabular}{|c|c|c|c|c|c|c|c|c|}
\hline & 1990 & 1994 & 1998 & 2002 & 2006 & 2008 & 2009 & 2010 \\
\hline Mundo & $\begin{array}{c}9.403,53 \\
(47,5)\end{array}$ & $\begin{array}{c}15.115,93 \\
(58,1)\end{array}$ & $\begin{array}{c}26.923,72 \\
(91)\end{array}$ & $\begin{array}{c}23.509,27 \\
(72)\end{array}$ & $\begin{array}{c}53.375,29 \\
(110)\end{array}$ & $\begin{array}{c}34.887,45 \\
(58,8)\end{array}$ & $\begin{array}{c}48.732,63 \\
(85,4)\end{array}$ & $\begin{array}{c}56.172,63 \\
(90,4)\end{array}$ \\
\hline EUA & $\begin{array}{c}3.060,00 \\
(53,2)\end{array}$ & $\begin{array}{c}5.067,02 \\
(72,5)\end{array}$ & $\begin{array}{c}13.451,35 \\
(153,9)\end{array}$ & $\begin{array}{c}11.098,10 \\
(104,8)\end{array}$ & $\begin{array}{c}19.425,85 \\
(145,7)\end{array}$ & $\begin{array}{c}11.737,65 \\
(82,1)\end{array}$ & $\begin{array}{c}15.077,29 \\
(107,4)\end{array}$ & $\begin{array}{c}17.138,98 \\
(117,5)\end{array}$ \\
\hline $\begin{array}{l}\text { Reino } \\
\text { Unido }\end{array}$ & $\begin{array}{c}849,00 \\
(83,8)\end{array}$ & $\begin{array}{c}1.210,25 \\
(114,1)\end{array}$ & $\begin{array}{c}2.374,27 \\
(163,1)\end{array}$ & $\begin{array}{c}1.864,26 \\
(115,6)\end{array}$ & $\begin{array}{c}3.794,31 \\
(155,2)\end{array}$ & $\begin{array}{c}1.851,95 \\
(69,7)\end{array}$ & $\begin{array}{c}2.796,44 \\
(128,7)\end{array}$ & $\begin{array}{c}3.107,04 \\
(138,3)\end{array}$ \\
\hline França & $\begin{array}{c}314,00 \\
(25,2)\end{array}$ & 451,26 (33) & $991,48(67,5)$ & $966,96(66,6)$ & $\begin{array}{c}2.428,57 \\
(107,7)\end{array}$ & $\begin{array}{c}1.492,33 \\
(52,7)\end{array}$ & $\begin{array}{c}1.972,04 \\
(75,1)\end{array}$ & $\begin{array}{c}1.926,49 \\
(75,3)\end{array}$ \\
\hline Japão & $\begin{array}{c}2.920,00 \\
(95,5)\end{array}$ & $\begin{array}{c}3.719,91 \\
(77,8)\end{array}$ & $\begin{array}{c}2.495,76 \\
(64,7)\end{array}$ & $\begin{array}{c}2.126,08 \\
(54,3)\end{array}$ & $\begin{array}{c}4.726,27 \\
(108,3)\end{array}$ & $3.220,49(66)$ & $\begin{array}{c}3.377,89 \\
(67,1)\end{array}$ & $\begin{array}{c}4.099,59 \\
(74,6)\end{array}$ \\
\hline Espanha & $\begin{array}{c}111,00 \\
(21,3)\end{array}$ & $154,86(30,1)$ & $402,18(66,9)$ & $465,00(67,8)$ & $\begin{array}{c}1.323,09 \\
(107,2)\end{array}$ & $946,11(59,4)$ & $\begin{array}{c}1.297,23 \\
(88,6)\end{array}$ & $\begin{array}{c}1.171,61 \\
(83,2)\end{array}$ \\
\hline Brasil & $16,40(3,6)$ & $189,00(34,6)$ & $160,89(19,1)$ & $123,81(24,6)$ & $711,10(65,3)$ & $589,38(35,7)$ & $\begin{array}{c}1.167,33 \\
(73,2)\end{array}$ & $1.545,57(74)$ \\
\hline $\begin{array}{c}\text { Alemanh } \\
\text { a }\end{array}$ & $\begin{array}{c}355,00 \\
(20,7)\end{array}$ & $470,52(21,9)$ & $\begin{array}{c}1.093,96 \\
(50,1)\end{array}$ & $691,12(34,3)$ & $\begin{array}{c}1.637,83 \\
(56,1)\end{array}$ & $\begin{array}{c}1.107,96 \\
(30,5)\end{array}$ & $1.297,57$ (39) & $\begin{array}{c}1.429,71 \\
(43,2)\end{array}$ \\
\hline Portugal & $9,20(11,9)$ & $16,25(16,5)$ & $62,95(51,4)$ & $42,85(32,5)$ & $104,20(51,8)$ & $68,71(27,3)$ & $98,65(42,1)$ & $82,00(35,9)$ \\
\hline Grécia & $\begin{array}{l}15,20 \\
(16,1)\end{array}$ & $14,92(13,3)$ & $79,99(58,6)$ & $68,74(46,6)$ & $208,28(78,6)$ & $90,40(26)$ & $54,72(16,8)$ & $72,64(23,8)$ \\
\hline $\begin{array}{l}\text { Hong- } \\
\text { Kong }\end{array}$ & $\begin{array}{r}83,40 \\
(108,5)\end{array}$ & $\begin{array}{l}269,51 \\
(198,8)\end{array}$ & $\begin{array}{l}343,39 \\
(205,7)\end{array}$ & $\begin{array}{l}463,08 \\
(282,7)\end{array}$ & $\begin{array}{l}895,25 \\
(471,4)\end{array}$ & $\begin{array}{c}1.328,84 \\
(617)\end{array}$ & $\begin{array}{c}2.291,58 \\
(1095)\end{array}$ & $\begin{array}{l}2.711,33 \\
(1207,9) \\
\end{array}$ \\
\hline Índia & $\begin{array}{l}38,60 \\
(13,2)\end{array}$ & $128,00(39,6)$ & $105,19(25,3)$ & $131,01(25,8)$ & $818,88(86,1)$ & $645,48(53,2)$ & $\begin{array}{c}1.179,24 \\
(85,4)\end{array}$ & $\begin{array}{c}1.615,86 \\
(93,5)\end{array}$ \\
\hline Irlanda & n.d. & n.d. & $66,60(75,7)$ & $60,38(49,2)$ & $163,36(73,4)$ & $49,40(18,7)$ & $29,88(13,5)$ & $33,72(16,5)$ \\
\hline
\end{tabular}

Tabela 1: Capitalização bolsista (em 109 USD) e relação entre esta e o PIB (\% entre parêntesis)

Fonte: Elaboração própria, a partir de informação disponível em http://data.worldbank.org/; n.d. - não disponível.

\begin{tabular}{|c|c|c|c|c|c|c|c|c|c|}
\multicolumn{1}{c|}{} & 1990 & $\mathbf{1 9 9 4}$ & $\mathbf{1 9 9 8}$ & $\mathbf{2 0 0 2}$ & $\mathbf{2 0 0 6}$ & $\mathbf{2 0 0 7}$ & $\mathbf{2 0 0 8}$ & $\mathbf{2 0 0 9}$ & $\mathbf{2 0 1 0}$ \\
\hline Mundo & 28,2 & 33,9 & 75,1 & 115,5 & 139,2 & 182,0 & 135,7 & 142,7 & 104,6 \\
\hline Estados Unidos & 30,5 & 51,0 & 150,4 & 239,6 & 249,5 & 304,5 & 255,1 & 332,8 & 208,8 \\
\hline Reino Unido & 27,5 & 43,8 & 80,2 & 118,5 & 173,6 & 367,3 & 244,1 & 156,6 & 133,9 \\
\hline França & 9,4 & 22,5 & 40,3 & 64,4 & 111,0 & 132,4 & 115,3 & 52,0 & 32,3 \\
\hline Japão & 52,4 & 23,5 & 24,6 & 40,2 & 143,3 & 148,4 & 120,5 & 83,3 & 77,9 \\
\hline Espanha & 7,9 & 11,9 & 116,3 & 147,8 & 156,4 & 205,4 & 153,1 & 109,2 & 66,6 \\
\hline Brasil & 1,2 & 20,0 & 17,4 & 9,6 & 23,4 & 42,8 & 44,0 & 40,7 & 43,2 \\
\hline Alemanha & 29,3 & 21,5 & 34,9 & 61,1 & 85,2 & 101,0 & 85,4 & 38,7 & 42,5 \\
\hline Portugal & 2,2 & 5,4 & 38,8 & 15,4 & 34,9 & 62,3 & 32,8 & 19,5 & 13,7 \\
\hline Grécia & 4,2 & 4,6 & 34,3 & 16,9 & 40,5 & 48,8 & 13,9 & 15,8 & 14,1 \\
\hline Hong-Kong & 45,0 & 108,6 & 123,4 & 128,6 & 212,6 & 442,8 & 755,1 & 711,8 & 711,7 \\
\hline India & 6,9 & 8,5 & 35,6 & 38,9 & 67,1 & 89,1 & 86,5 & 78,9 & 61,1 \\
\hline Irlanda & & 7,9 & 48,2 & 26,8 & 35,9 & 52,7 & 14,1 & 8,3 & 8,2 \\
\hline
\end{tabular}

Tabela 2: Valor das Ações negociadas, em percentagem do PIB

Fonte: Elaboração própria, a partir de informação disponível em http://data.worldbank.org/ . 
Um crash ou queda bolsista ocorre quando se verifica uma descida anormalmente acentuada nos preços dos ativos, envolvendo de forma generalizada todo o mercado (Jansen e DeVries, 1991). Em termos estatísticos, e de modo mais objetivo, essa descida acentuada dos preços deve ser relacionada com os percentis extremos da distribuição de rendibilidades de um índice de referência. Para os mesmos autores, quando um índice representativo de um determinado mercado sofre uma queda superior ao percentil 1 ou 5 da distribuição de rendibilidades históricas, ou seja, quando cai na extremidade esquerda da distribuição, ocorre um crash.

Em seguida analisamos, sumariamente, os crashes de 1929, 1987, 2000 e 2007, por serem os mais importantes, quer em termos da queda dos valores dos índices de ações quer da sua abrangência global.

\subsection{CRASH DE 1929}

O crash bolsista de 1929 iniciou-se em Nova lorque, tendo atingido o seu auge entre 24 e 29 de outubro de 1929. Este facto marcou o começo da maior crise económica do século XX, a chamada "Grande Depressão".

A figura 3 apresenta a evolução do índice Dow Jones e do respetivo volume de negociação, no período relativo à "Grande Depressão". Este índice tinha acumulado ganhos de 50\% em 1928 e de 25\% em 1929. Porém, uma conjuntura de desaceleração de alguns indicadores económicos fez com que o mercado bolsista invertesse a tendência de subida, levando a uma verdadeira loucura bolsista nos EUA, na análise de Rappoport e White (1994). De acordo com estes autores, o Dow Jones atingiu o seu valor máximo em 3/9/1929; menos de três anos depois, em 8/7/1932, acumulou perdas de quase 90\% do seu valor. Só nos dias 28 e 29 de outubro de 1929, o Dow Jones acumulou perdas de 23\%. Em simultâneo, durante estes dias, o número de ações negociadas aumentou significativamente. No dia 24/10/1929, dia conhecido por "quinta-feira negra", foram negociadas quase treze milhões de ações. No dia 29/10/1929, também conhecido por "terça-feira negra", foram negociadas mais de dezasseis milhões de ações. Em qualquer dos casos, o número de ações negociadas mais do que triplicou a média das semanas que antecederam esta crise económica, bolsista, e financeira.

As quedas acentuadas propagaram-se da bolsa dos EUA a outras praças mundiais, como a bolsa de Paris, cujo índice passou, num período aproximado de dois anos, do índice 507, em 9/1929, para o índice 269, em 9/1931 (Belletante, 1996). 

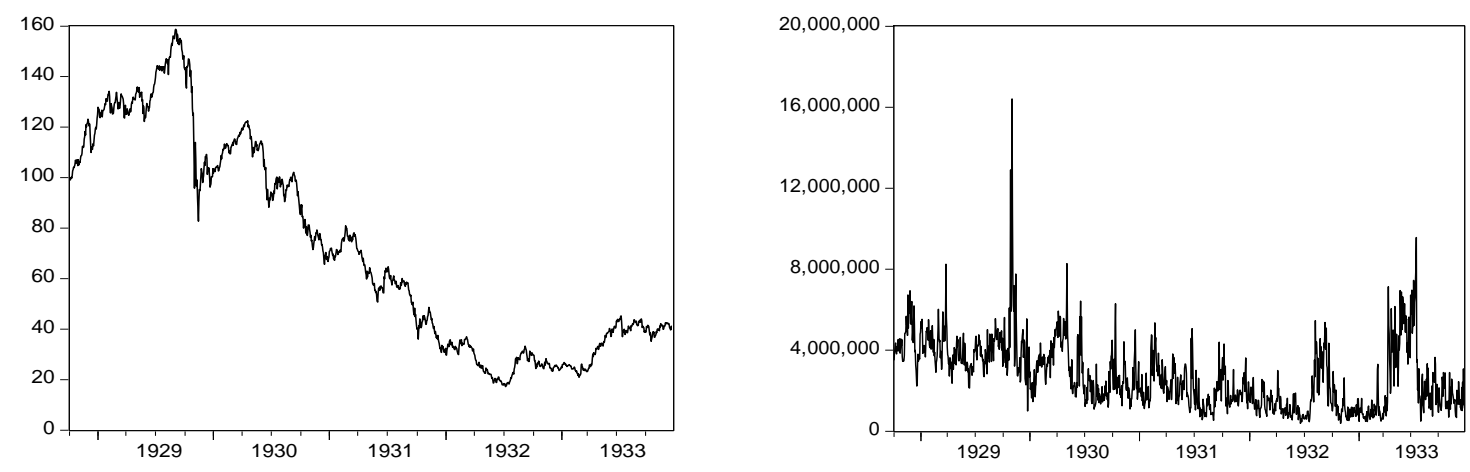

Figura 3: Evolução do índice Dow Jones (esq., 1/10/1928=100) e do seu volume de negociação (dir.) Fonte: www.yahoo.finance.com.

Aquando do crash de 1929, a bolsa baseava-se em três intervenientes: o comprador, o corretor e o banco. Todos estes intervenientes estavam interessados na subida acentuada e constante dos preços dos títulos, ignorando os princípios fundamentais de avaliação de ativos. Em múltiplas situações, as operações de compra de títulos faziam-se com recurso a crédito e na expectativa de obtenção de margens elevadas. Em meados de 1929, estas margens chegavam aos 50\% na maioria das ações e a 60 a 75\% nas de risco mais elevado (Wigmore, 1985). Em muitas destas operações a compra de ações era feita a descoberto, com o comprador a pedir emprestado o valor equivalente ao da compra, dando como garantia do empréstimo os próprios títulos. Atingida uma valorização satisfatória para o comprador, este vendia os títulos com uma mais-valia e reembolsava o corretor, que também cobrava uma taxa de juro elevada, pois também tinha recorrido a um empréstimo bancário, pelo qual tinha pago uma taxa de juro elevada ao banco, que tinha pago igualmente juros elevados aos seus depositantes, entrandose, assim, num ciclo vicioso.

Em operações com estas caraterísticas, altamente especulativas, o valor intrínseco dos ativos parece ser o menos importante. Se em dado momento, os preços dos títulos começam a descer, em função de más notícias económicas ou da previsão do esgotamento do potencial de crescimento da economia, os investidores tomam a decisão de vender, passando de um ciclo de alta para um de baixa. Assim, os preços dos títulos, dados como garantia aos corretores, sofrem uma descida e os corretores propõem aos seus clientes um ajustamento das margens do negócio, não em função do valor dos títulos, mas do valor do empréstimo concedido. Para fazer face à proposta do corretor, o investidor precisa de vender para obter liquidez. A pressão com vista à venda dos títulos alimenta o movimento de queda dos seus preços. Foi o que aconteceu em outubro de 1929 (Kindleberger, 2000).

De acordo com Galbraith (2009), a facilidade de obtenção de crédito para a compra de ações não é suficiente para explicar a elevada especulação registada na bolsa de Nova lorque, no período em causa, pois noutros períodos houve as mesmas facilidades de crédito, sem se sucederem tais especulações bolsistas. O mesmo autor defende que foram cinco as causas da crise financeira de 1929: os desequilibrios na distribuição da riqueza, as fraquezas ou 


\section{Egitania}

$s$ c i e $\Omega$ c i a

debilidades das estruturas empresariais, as falhas ocorridas na estrutura bancária (com um grande número de unidades independentes), as dúvidas quanto à situação da balança comercial e a má qualidade da informação económica.

Para se tentar evitar a repetição de outros crashes de igual magnitude, a partir daí as operações bolsistas a crédito foram mais controladas, as exigências de cobertura e garantia foram mais rigorosas, as empresas foram obrigadas à divulgação de informação financeira e foi criada a primeira instituição de vigilância do mercado, a Securities Exchange Comission (SEC).

\subsection{CRASH DE 1987}

No período compreendido entre 1981 e 1986, os mercados de capitais estiveram muito ativos, passando a funcionar 24 horas por dia. De acordo com Belletante (1996), ocorreram três situações que foram responsáveis pela mudança nos mercados: um movimento de desregulamentação, que se traduziu na eliminação de diversas restrições legislativas nacionais e do controlo de câmbios; o desenvolvimento acelerado das TIC, que permitiram operações em tempo real e em qualquer praça financeira mundial, contribuindo, assim, para aumentar a intensidade de circulação de capitais, de arbitragem, mas também de especulação; e o aumento do número e tipo de produtos financeiros, cada vez mais complexos e desconhecidos, o que alargou as possibilidades de proteção e, simultaneamente, de especulação.

Rogoff e Reinhart (2010) concluíram que o facto de não terem ocorrido anomalias graves nas bolsas mundiais, no lapso de tempo de 1950 a 1987, com os sistemas de regulamentação até então criados a revelarem-se aparentemente eficazes, levou a que, no ano de 1987, ocorresse um dos mais fortes crashes da história das bolsas mundiais.

A figura 4 apresenta a evolução dos índices Dow Jones, FTSE e Hang-Seng, cujas trajetórias mostram bem os ganhos significativos acumulados desde o início do ano de 1987 (superiores a 40\% nos dois primeiros casos e a 50\% no último caso) e as quedas abruptas ocorridas em 19/10 desse ano, dia que ficou conhecido como "segunda-feira negra" e em que o índice Dow Jones registou uma perda intradiária de $23 \%$ do seu valor.

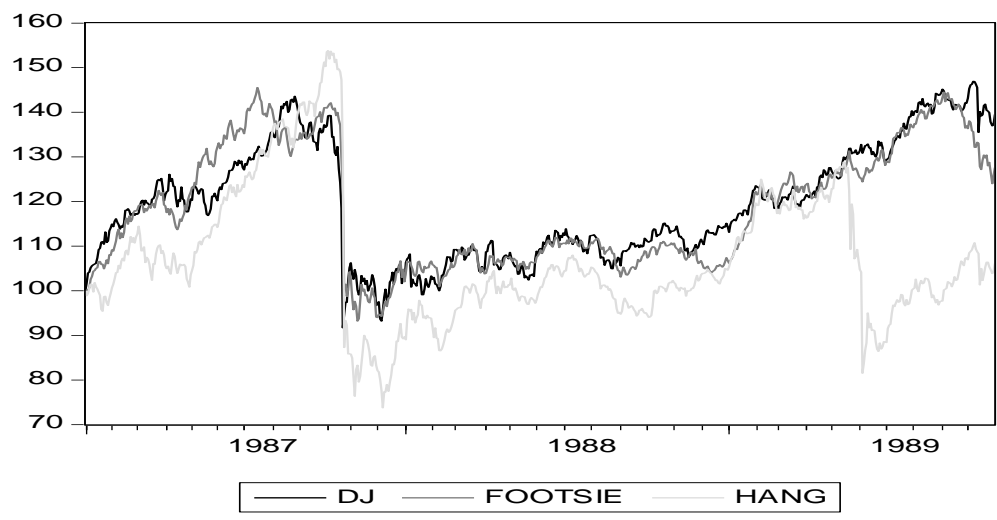

Figura 4: Evolução dos índices Dow Jones, Footsie e Hang-Seng

$(13 / 12 / 1986=100)$

Fonte: www.yahoo.finance.com. 


\section{Egitania}

$s$ c i e $\Omega$ c i a

Wigmore (1997) refere quatro tipos de causas que levaram ao crash de 1987: económicas, monetárias, financeiras e de gestão de carteiras. As do foro económico estão relacionadas com o facto de os mercados financeiros não poderem viver isolados da economia real, o que aconteceu com os EUA, que acumulavam elevados défices orçamentais e comerciais. A redução destes teria um efeito recessivo sobre as economias dos EUA e mundial, penalizaria os resultados das empresas e poria em causa a escalada dos preços das ações; nestas condições nenhuma decisão foi tomada para cortar o mal pela raiz. As causas monetárias prendem-se com os movimentos descritos pelas principais moedas internacionais, cujas oscilações poderiam pôr em causa a economia mundial, o que levou a que, no início de 1987, os sete países mais ricos do mundo (o G7) assinassem o acordo do Louvre, com o objetivo de estabilizar as respetivas moedas, mas cuja implementação levaria a alguns desentendimentos entre os subscritores. O limitado esforço de redução dos défices contribuiu para a subavaliação do dólar, obrigando a intervenções dos bancos centrais europeus e japonês, de modo a sustentá-lo, facto que fez com que, para evitar um aumento da massa monetária, os países credores dos EUA aumentassem as taxas de juro, o que não foi aceite pelos EUA, por recearem uma travagem do crescimento económico mundial e por entenderem que estas decisões poderiam ser interpretadas pelos investidores como uma "guerra" monetária, o que poderia ter como consequência uma recessão mundial. A causa de índole financeira baseia-se nos pressupostos fundamentais da valorização de ativos financeiros, pois a conjugação da forte volatilidade da cotação do dólar, do receio de tensões inflacionistas e de elevadas taxas de juro levou a que os investidores tivessem que escolher entre ações e obrigações.

A designada "portfolio insurance", enquanto técnica de gestão de carteiras, pretende maximizar o movimento de subida da cotação e minimizar o risco máximo de queda, através de um nível pré-definido pelo investidor. A aplicação desta técnica é facilitada com a utilização de sofisticado software informático que, baseando-se num afastamento entre o "a prazo" e o "à vista", permite estratégias de arbitragem, em especial na venda de ações à vista, para comprar contratos a prazo sobre índices. Em outubro de 1987 o afastamento entre as compras à vista e a prazo atingiu valores muito significativos, de 20 a 30\%, o que resultou na venda massiva de produtos à vista, que criou uma espiral descendente, não compensada pelas estratégias de arbitragem, facto que abanou com violência os mercados bolsistas mundiais.

\subsection{CRASH DAS EMPRESAS TECNOLÓGICAS}

Na década de 1990, as bolsas de valores dos países desenvolvidos assistiram a uma rápida subida dos preços das ações das chamadas empresas tecnológicas ou das chamadas empresas da nova economia, recorrendo à expressão de Sornette (2004), que inclui, entre outras, empresas que desenvolvem atividades relacionadas com a internet, o software, o hardware e as telecomunicações. A rápida valorização destes títulos, intensificada pela especulação bolsista e pela elevada disponibilidade de capital de risco, criou um ambiente de euforia nos mercados. 


\section{Egitania}

$s$ c i e $\Omega$ c i a

Segundo Kindleberger e Aliber (2005), em 1990, o valor de mercado das ações negociadas no índice NASDAQ equivalia a 11\% da bolsa de valores de Nova lorque, o que compara com os anos de 1995 e 2000, cujas percentagens passaram a 19\% e 42\%, respetivamente. Na primeira metade da década de 1990, o crescimento médio anual do valor de mercado dos títulos do índice NASDAQ foi de 30\%, enquanto nos quatro anos seguintes foi de $46 \%$.

A figura 5 apresenta a evolução da cotação do índice tecnológico Nasdaq e do seu volume de negociação, no período compreendido entre 1995 e 2003. No início de 1995 este índice registou o valor de 750 pontos. Em 10/3/2000 atingiu um valor máximo de 5049 pontos e em 14/4, pouco mais de um mês depois, teve uma queda abrupta de 34\%, ao cair para o valor de 3321 pontos. Estas quedas do índice estiveram associados a volumes de negociação anormalmente elevados, em particular durante o ano de 2001, mas as quedas do índice continuaram até atingirem o valor de 1114 pontos, em 9/10/2002. Nos anos de 2000 a 2003, as bolsas americanas, no seu conjunto, sofreram uma queda de cerca de $40 \%$ do seu valor (Kindleberger e Aliber, 2005).
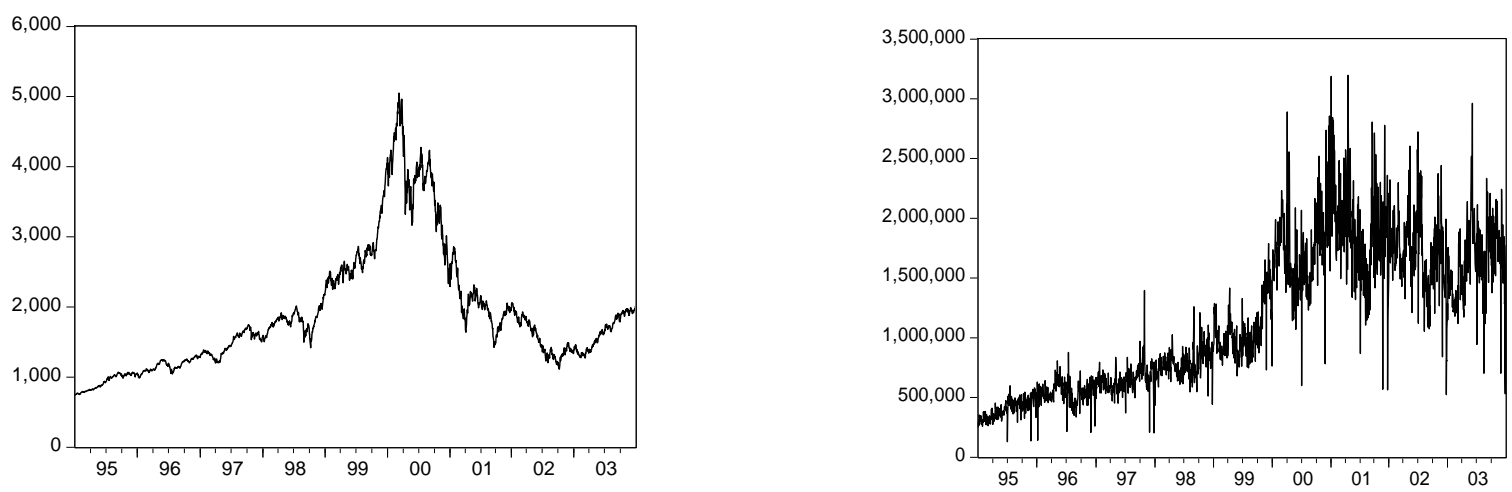

Figura 5: Evolução diária do índice NASDAQ (esq) e do seu volume de negociação (dir) Fonte: www.yahoo.finance.com.

A figura 6, elaborada a partir de dados obtidos no sítio yahoo.finance.com, mostra que as quedas acabaram por chegar a outros índices e a outros países, como foram os casos do DJ, do FTSE e do NIKKEl, embora a magnitude das quedas tenha sido bastante inferior à que ocorreu no índice NASDAQ. 


\section{Egitania}

$\mathrm{s}$ c i e $\Omega$ c i a

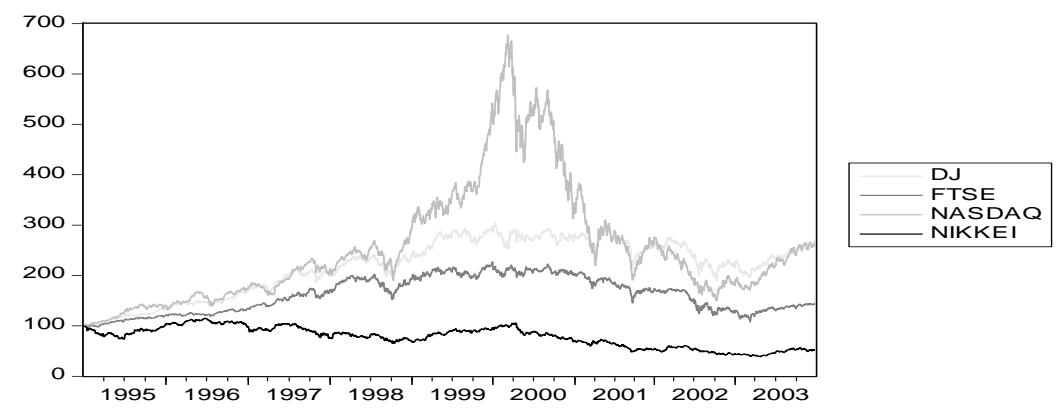

Figura 6: Evolução diária dos índices Nasdaq, DJ, FTSE e Nikkei Notas: Esta figura apresenta a evolução do índice Nasdaq e do seu volume de negociação, expresso em milhares, no período compreendido entre 4 de janeiro de 1995 e 30 de dezembro de 2003. O dia 4 de janeiro de 1995 foi considerado a base 100. A figura foi elaborada a partir de dados obtidos em yahoo.finance.com.

Segundo Sornette (2004), o apetite por ações de empresas tecnológicas resulta do facto destas empresas apresentarem um price earning ratio (PER) que pode chegar a ser maior ou igual que 100, ao contrário das empresas da "velha economia", cujo PER médio é de 10. A diferença entre as ações da velha e da nova economia reside nas expectativas de rentabilidades futuras, com os investidores a trocarem a falta de rentabilidades atuais pela perspetiva de elevadas rentabilidades potenciais. No essencial, esta situação significou que o bull market, registado na década de 1990, foi sustentado em perspetivas de ganhos futuros, mais do que em bons fundamentos económicos das empresas, o que conduziu a uma bolha especulativa, com os investidores a tentaram comprar participações em empresas, que pudessem ter o sucesso de empresas como a Microsoft, a Intel, a Cisco ou a Dell. Esta situação mostra que os investidores podem seguir um processo de imitação ou comportamento de massas, que conduz à "construção de castelos no ar", recorrendo à expressão de Malkiel (1989).

\subsection{CRISE SUBPRIME E DAS DÍVIDAS SOBERANAS}

Após o crescimento dos índices bolsistas, verificado na segunda metade da década de 1990, registou-se uma queda destes, em consequência da já referida crise das empresas tecnológicas. A situação de queda das bolsas e os atentados contra as torres gémeas, em 11 de setembro de 2001, antecederam um período de crescimento económico mais moderado. Para estimular o mercado imobiliário, o consumo, o investimento e a produção, a Reserva Federal norte-americana tomou a decisão de baixar as taxas de juro (Banco de Portugal, 2008). Ao mesmo tempo, a banca de investimento e a banca comercial privilegiaram a adoção do modelo "originar e distribuir", baseado na criação de crédito e sua posterior securitização, de modo a permitir uma maior libertação de capital, para fazer face a outras operações de financiamento, o que permitiu uma concessão de crédito de forma quase ilimitada (Bhatia, 2007; Gorton, 2009; Purnanandam, 2009), conduzia à concessão de crédito de forma quase ilimitada. Esta situação criou múltiplas oportunidades de negócio, quer no risco de crédito para 


\section{Egitania}

s c i e $\Omega$ c i a

seguradoras, quer nos fundos de pensões, quer em hedge funds ${ }^{5}$. Num contexto de taxas de juro baixas, em particular no mercado das obrigações, e de facilidade de acesso ao crédito, os investidores procuraram alternativas de investimento potencialmente mais rentáveis, embora com maior risco. Para além disso, verificou-se uma maior procura de produtos com estrutura mais complexa, como os Residential Mortgage-Baked Securities, os Collateralized Debt Obligations e os Collaterized Loan Obligations ${ }^{6}$, mas também a alavancagem dos mesmos, na tentativa de se obter taxas de rentabilidade mais elevadas. Com a crescente complexidade dos produtos, os investidores passaram a ter menos informação acerca dos mesmos, cobrindo esse défice de informação com a avaliação feita pelas agências de rating. Na opinião de Getter et al. (2007), o modelo adotado pelas instituições de crédito facilitou a securitização do crédito hipotecário, mas também a disseminação do risco pelo sistema financeiro.

Segundo DiMartino e Duca (2007), as situações de maior risco estavam ligadas a empréstimos subprime. Estes empréstimos eram habitualmente designados por empréstimos "ninja" (no income, no job and no assets), destinando-se a uma parcela da população sem rendimento, sem emprego fixo, sem ativos que servissem como garantia, mas também sem historial de crédito.

Durante o ano de 2005, nos EUA, as taxas de incumprimento dos empréstimos subprime aumentaram de forma assinalável, devido a três ordens de razões: i) a taxa dos empréstimos subprime era variável, sendo em geral mais reduzida nos dois primeiros anos ${ }^{7}$; embora em 2004 as taxas de juro de curto prazo tivessem sofrido um aumento significativo, só mais tarde se começou a sentir o efeito nas prestações dos empréstimos; ii) os preços do mercado habitacional registaram valorizações acentuadas, muito acima do que as taxas de crescimento populacional ou os custos de construção faziam supor, principalmente a partir do início do presente século (vide figura 7, elaborada a partir de Shiller, 2006); iii) muitas familias americanas adquiriram casa, com o objetivo de posteriormente renegociarem a dívida. Porém, antes de muitos empréstimos serem renegociados, como estava previsto previamente, ocorreu um aumento significativo das taxas de juro dos empréstimos, acompanhado de uma queda dos preços habitacionais; tendo em conta a informação mostrada na figura 7, só no ano de 2007 as quedas dos preços foram superiores a 20\%, mantendo-se essa tendência de queda até ao ano de 2009; comparando o pico dos preços habitacionais, registado em meados de 2006, com o mínimo registado no início de 2009 resultou numa perda acumulada de cerca de 32\%.

\footnotetext{
5 Um Hedge Fund é um fundo de investimento criado para se obter a maior rentabilidade possível, recorrendo a diversas alternativas de investimento e a técnicas de mercado à disposição do gestor, como são os instrumentos derivados, mas sem qualquer tipo de limite, de modo a reduzir o risco do investimento e a obter um rendimento atrativo e independente da evolução dos mercados financeiros. Os Hedge Fund são fundos relativamente complexos e mais vocacionados para investidores profissionais e detentores de elevado património, estando, em geral, domiciliados em zonas fiscalmente eficientes.

6 Os primeiros dizem respeito a títulos de securitização que envolvem empréstimos hipotecários residenciais; os segundos são instrumentos de dívida estruturados, cujos colaterais são garantidos por carteiras que podem incluir dívida de diversos tipos, nomeadamente obrigações, empréstimos concedidos a empresas por credores institucionais e ainda conjuntos de instrumentos titularizados; os terceiros são também instrumentos estruturados, cujos colaterais são garantidos por empréstimos com pagamentos titularizados em diferentes tranches, sendo as titularizações garantidas pelas instituições financeiras, através das rendas dos empréstimos.

7 Esta modalidade é conhecida por "adjustable-rate mortgages" (ARM); contempla taxas de juro muito baixas nos primeiros anos do empréstimo e bastante mais elevadas nos anos seguintes, favorecendo o endividamento das famllias. Segundo Kregel (2008), o número de empréstimos subprime, com recurso ao mecanismo ARM, cresceu significativamente no período de 2001 a 2006. No ano de 2005, 93\% dos empréstimos concedidos envolviam esta modalidade.
} 


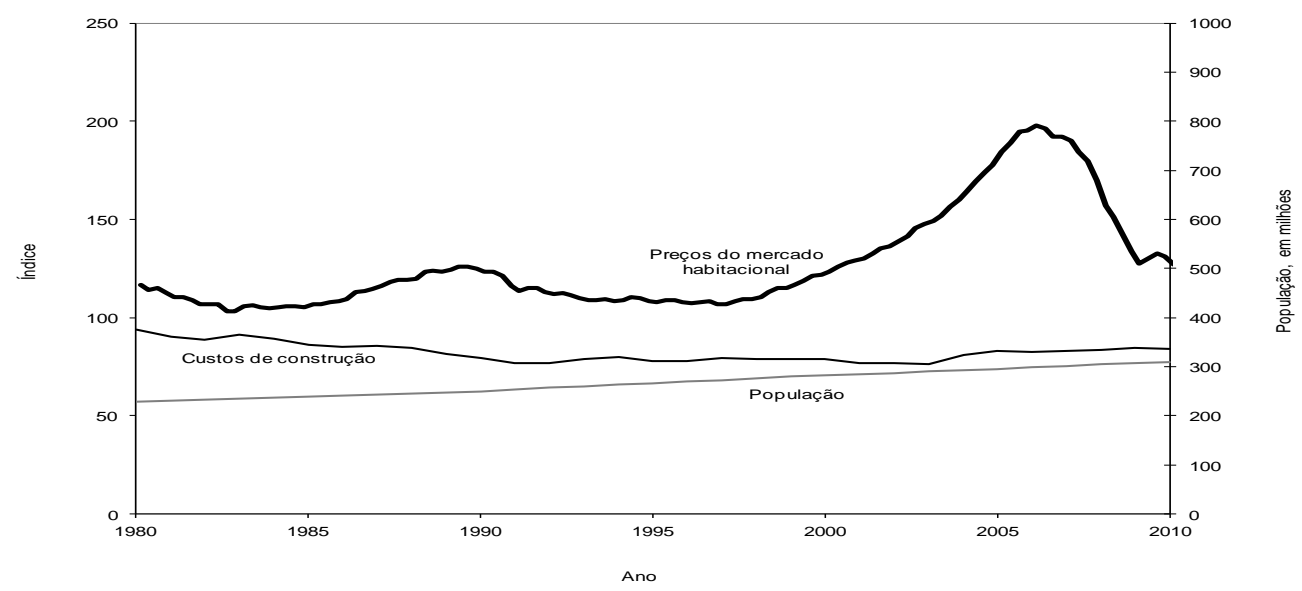

Figura 7: Evolução dos preços do mercado habitacional, dos custos de construção e da população nos EUA

Fonte: Shiller (2006) e informação disponibilizada pelo autor em http://www.econ.yale. edu/ shiller/data.htm. Consultado em 2013.

Segundo Getter et al. (2007), em 2007, nos EUA, registou-se um enorme aumento da taxa de incumprimento dos empréstimos hipotecários contratados nos anos de 2005 e 2006. As situações de incumprimento, resultantes das subidas das taxas de juro e da descida dos preços dos imóveis, ajudaram, por um lado, a criar a perceção de que os empréstimos tinham sido concedidos de acordo com pressupostos demasiado otimistas, o que motivou uma reavaliação do risco e a consequente diminuição da oferta de crédito. Por outro lado, o sentimento de que os investidores tinham adquirido ativos expostos a um elevado risco de liquidez gerou tensões financeiras generalizadas. Essa situação foi facilitada pelas complexas ligações entre os mercados de crédito e financeiro, atingindo muito rapidamente todo o sistema financeiro norteamericano, denunciando assim as fragilidades sistémicas do mesmo. A tentativa de venda destes ativos acabaria por gerar tensões e por se propagar aos restantes ativos do mercado de capitais, contribuindo para o desenvolvimento de uma crise patrimonial. A situação agravouse com a crise de liquidez de um dos maiores bancos de Wall Street, o Bear Stearns, que viria a ser absorvido pelo JP Morgan Chase, em 2008. Em setembro deste ano, as empresas hipotecárias Fannie Mae e Freddie Mac foram resgatadas pelo Governo norte-americano, por se entender que estas representavam um risco sistémico para a estabilidade do sistema financeiro do país. Ainda nesse ano, o banco Lehman Brothers declarou falência e, poucos dias depois, o mesmo aconteceu com o grupo segurador American International Group (AIG), cuja atividade tinha uma grande expressão no mercado dos Credit Default Swaps (CDS)8. No início de outubro de 2008, depois de um processo algo conturbado, marcado por avanços e recuos, a Câmara dos Representantes e o Senado dos EUA aprovaram um plano de resgate financeiro,

8 Estes contratos permitem às entidades detentoras de dívida fazer seguros contra riscos de incumprimento. Grande parte dos grandes bancos europeus, que desenvolviam atividade nos EUA, estava segurada pelo American International Group (AIG). 
também conhecido por Plano Paulson, que envolveu a afetação de 700 mil milhões de dólares no apoio a empresas em dificuldades, devido à crise económica e financeira.

A conjugação de todos estes elementos gerou um sentimento de grande desconfiança dos investidores no sistema financeiro. Este sentimento viria a propagar-se um pouco por todo o mundo, através de movimentos de pânico nos preços dos produtos primários, nos mercados de ações e de obrigações, com reflexos nas taxas de câmbio e, consequentemente, nas balanças de pagamentos das respetivas economias, mas também no financiamento das dívidas soberanas. Reinhart e Rogoff (2009) chegaram à conclusão de que as crises financeiras, em geral, são caraterizadas por longas e sustentadas quedas dos preços dos ativos, seguidas por quedas no PIB, por aumento do desemprego e da dívida pública, assim como de custos de resgate e de dificuldades de implementação de pacotes de estímulo, para relançar a economia.

No mercado de ações o impacto da crise subprime fez-se sentir um pouco por todo o mundo. A figura 8 apresenta a evolução de vários índices, calculados pela Morgan Stanley Capital International, para o período de 1/01/2003 a 21/10/2011. Os índices representativos da União Europeia, dos mercados mundiais, dos mercados desenvolvidos e dos mercados emergentes registaram quedas simultâneas, principalmente a partir de agosto de 2008, em consequência da crise do subprime.

De acordo com Bekaert et al. (2011), embora a crise tivesse a sua origem nos EUA, designadamente no mercado das hipotecas ou subprime, rapidamente se transmitiu a outros setores da economia, bem como a outras economias, quer desenvolvidas quer emergentes. Esta situação fez com que alguns autores se refiram à atual crise financeira como a primeira crise global e a mais severa desde a "Grande Depressão" (Claessens et al., 2010; Bekaert et al., 2011; e Lin e Treichel, 2012). As suas consequências não se limitaram aos mercados de ações, mas produziram efeitos muito diversos, tendo contribuído também para evidenciar a problemática do endividamento e do crescimento económico das nações. 


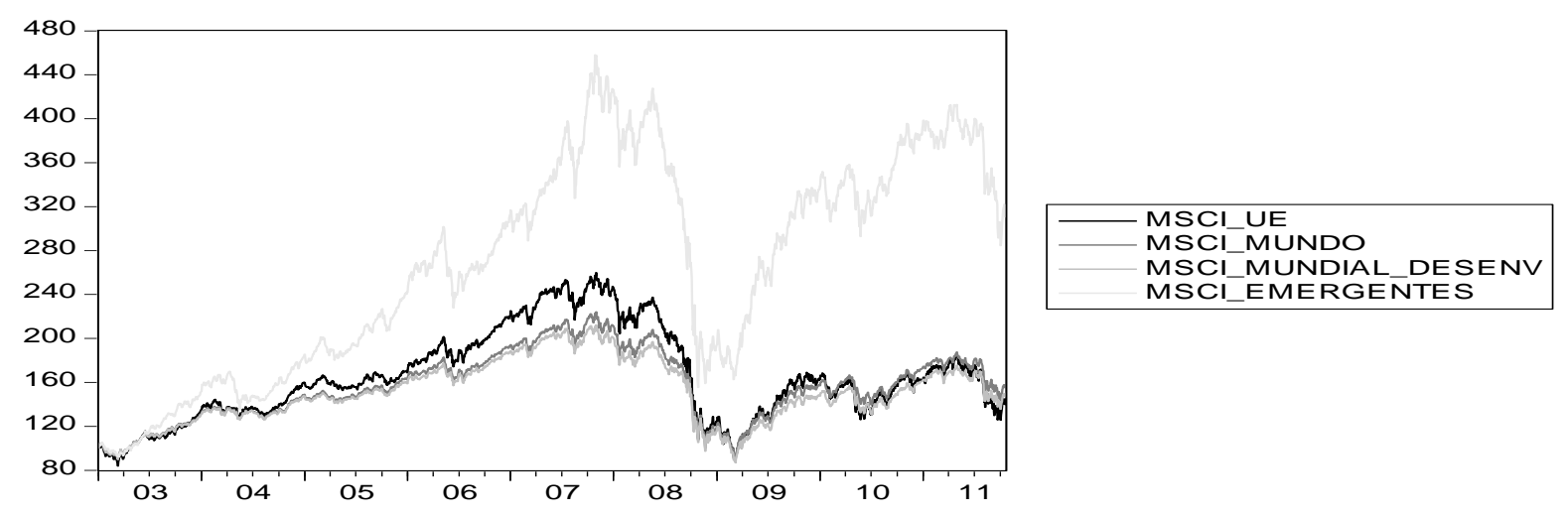

Figura 8: Evolução diária de alguns índices bolsistas mundiais Nota: os índices são representativos dos mercados dos países que integram a União Europeia (msci_UE), dos mercados mundiais (msci_mundo), dos mercados desenvolvidos (msci_mundial_desenv) e dos mercados emergentes (msci_emergentes), (1 de janeiro de 2003 e 21 de outubro de 2011). A base 100, corresponde a 1/1/2003. A figura foi elaborada com base em informação obtida em Stanley Capital International e http://www.mscibarra.com/products/indices/international_equi ty_indices/gimi/stdiNdex/perf ormance.html. Consultado em 2013.

As figuras 9, 10 e 11, elaboradas a partir de McKinsey (2010), mostram o rácio da dívida de diversos países, medido em percentagem do PIB, na primeira metade da década de 1990, em 2000 e em 2009, respetivamente. No referido rácio foram considerados quatro tipos de dívida: pública, instituições não financeiras, familias e instituições financeiras.

Em 2009, a França, a Itália, a Coreia do Sul, os EUA e a Espanha apresentaram níveis de endividamento global superiores a 300\% dos respetivos PIB's. Destes, destaca-se a Espanha, com o endividamento global a superar 350\% do PIB, tendo a dívida de Instituições Financeiras sofrido um incremento significativo, que passou de 11\% em 2000 para 82\% em 2009.

Dos países europeus, a dívida pública italiana é a que tem registado valores percentuais mais estáveis, embora em todos os períodos analisados esses valores sejam iguais ou superiores ao respetivo PIB, como se pode confirmar da comparação das figuras 9, 10 e 11.

Em todo o período analisado, a Alemanha tem a particularidade de não destacar nenhum dos tipos de dívida relativamente a outros. Apesar de entre 1991 e 2000 se ter registado um aumento de 60\% do endividamento, entre 2000 e 2009 a dívida estabilizou, tendo passado de terceira para oitava economia mais endividada. 


\section{Egitania}

s c i e $\Omega$ c i a

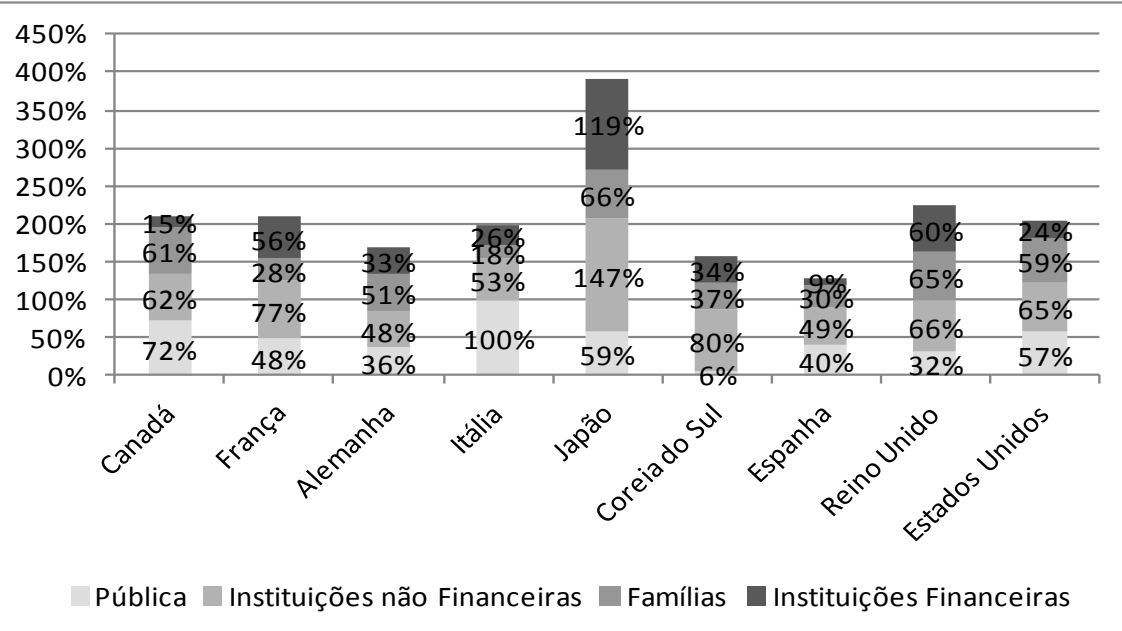

Figura 9: Evolução rácio de dívida de diversos países, em percentagem do PIB, no ano de 1990

Notas: Os dados expressam os níveis de endividamento total destas economias, em percentagem do PIB, no ano de 1990, exceto os casos da Alemanha, da França, e da Itália, cujos dados se reportam aos anos de 1991, 1994 e 1995, respetivamente. Em todos os casos, os dados foram obtidos em McKinsey (2010).

Em 2009, o Japão e o Reino Unido eram claramente os países mais endividados, apresentando um endividamento global superior a 450\% do PIB. Relativamente ao primeiro país, no ano de 2009, a dívida pública correspondia ao dobro do valor do PIB, tendo registado um aumento de cerca de 50\% em relação a 2000, como se pode concluir da análise das figuras 10 e 11.

Os EUA e o Canadá apresentaram níveis de endividamento inferiores aos dos países europeus, com a particularidade de, em ambos os casos, o tipo de dívida com mais peso ter sido o das familias, diferentemente dos restantes países. No primeiro caso, este tipo de dívida agravou-se em relação a 1990, por culpa do investimento na compra de habitação própria.

Países emergentes como o Brasil, a China, a Índia e a Rússia apresentavam níveis de endividamento muito inferiores aos dos restantes países, sendo a Rússia o país que apresentava menor endividamento global, de 71\% do PIB em 2008, e com a dívida pública a corresponder a 5\% do produto interno. 


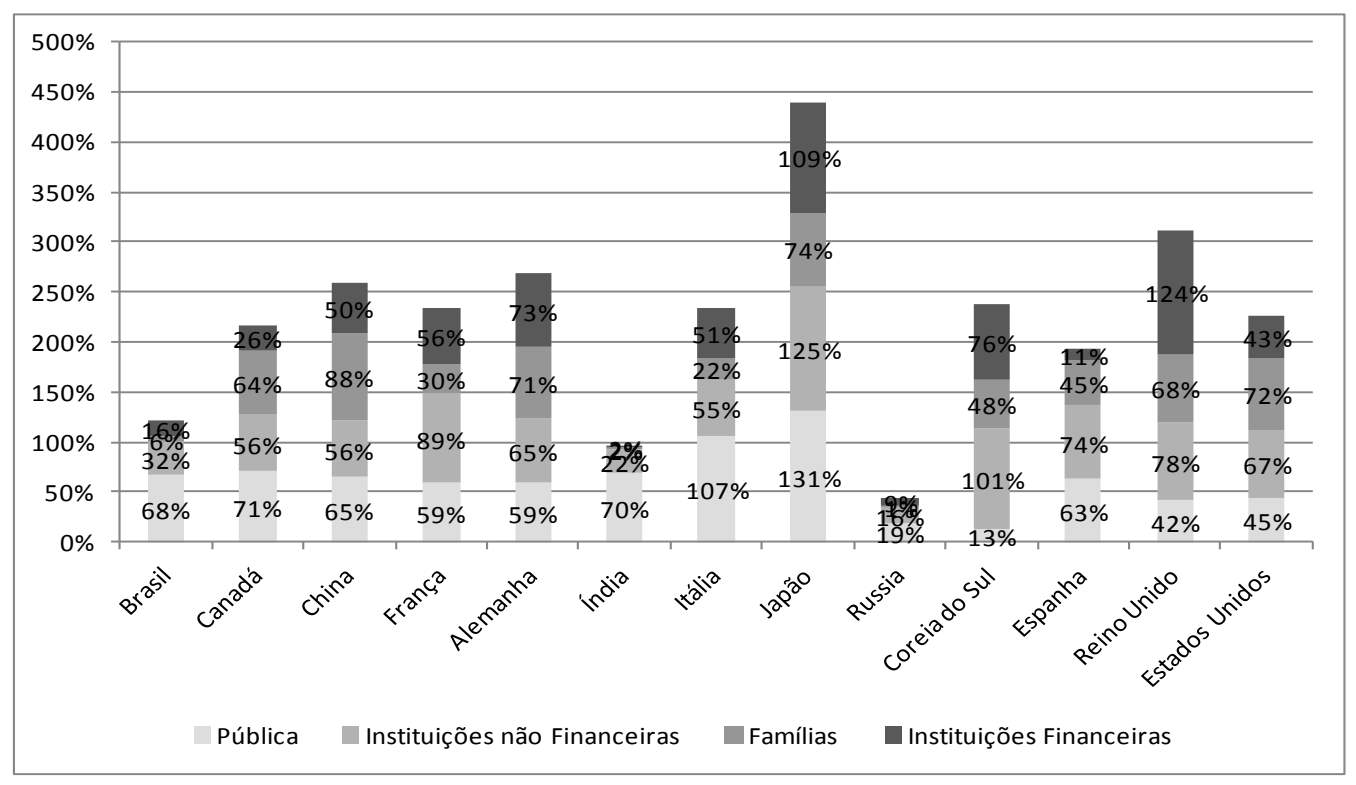

Figura 10: Evolução rácio de dívida de diversos países, em percentagem do $P I B$, no ano de 2000 Notas: Os dados expressam os níveis de endividamento total destas economias, em percentagem do PIB, no ano de 2000. Em todos os casos, os dados foram obtidos em McKinsey (2010).

Como foi referido anteriormente, no que à Europa diz respeito, as consequências da crise não se limitaram aos mercados bolsistas, tendo sido de diferentes tipos e de natureza muito diversa: a diferenciação entre os países europeus mais competitivos em termos económicos e os países periféricos, a criação do fundo europeu de estabilidade financeira (FEEF), em junho de 2010, o debate em torno do tema da integração europeia, o debate acerca dos derivados e da sua regulação, as implicações para a emissão de dívida pública, entre outras.

As consequências da crise não afetaram todos os países europeus uniformemente, havendo grandes diferenças entre as maiores economias (Alemanha e França) e as economias periféricas em crise (Grécia, Irlanda, Portugal, Espanha e Itália). Enquanto os países centrais vinham a registar uma relativa recuperação económica desde 2010, que atualmente parece estar também comprometida, os países periféricos estão confrontados com uma recessão económica de consequências e duração imprevisíveis.

A recente crise financeira acabaria por trazer mudanças ao nível da emissão de dívida pública nos dezasseis países da zona euro, que antes da crise se baseava num padrão comum, que envolvia a colocação de dívida a longo prazo e a aplicação de taxas fixas de dívida. DeBroeck e Guscina (2011) concluíram que, depois de meados de 2008, não foi possível a manutenção deste padrão comum, devido ao aumento das necessidades de financiamento soberano (dos países) e à aversão dos investidores ao risco, factos que desencadearam uma subida dos prémios de risco. 


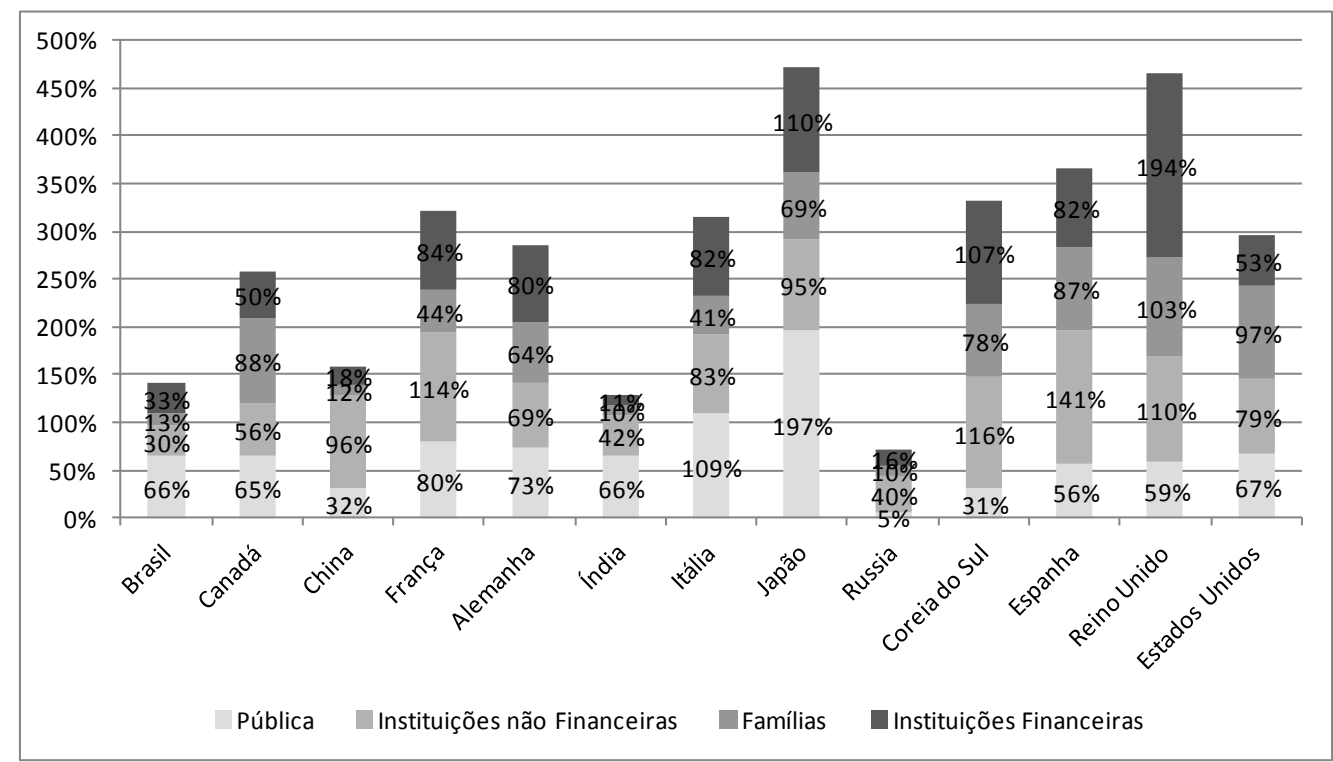

Figura 11: Evolução rácio de dívida de diversos países, em percentagem do PIB, no ano de 2009 Notas: Os dados expressam os níveis de endividamento destas economias, em percentagem do PIB, no ano de 2009, exceto os casos da Rússia, da Índia, do Brasil e da China, cujos dados se reportam ao ano de 2008. Os dados foram obtidos em McKinsey (2010).

DeBroeck e Guscina (2011) desenvolveram uma investigação baseada em 3000 emissões de dívida dos governos da zona euro e da Dinamarca, no período compreendido entre 2007 e 2009, cujas conclusões destacam o aparecimento de um novo padrão de emissão de dívida pública, que privilegia prazos mais curtos na emissão de dívida (porque minimizadores de risco para o investidor), denominada em moeda estrangeira (transferência da exposição do risco da moeda do país de origem do investidor para o devedor) e/ou taxas flutuantes.

Os efeitos negativos da crise foram especialmente pronunciados nos países com défices orçamentais elevados e com dívida pública elevada. De acordo com DeBroeck e Guscina (2011), a referida mudança no padrão de dívida pública obrigou os governos a lidar com o reduzido "apetite" dos investidores pelo risco e a limitar o impacto de défices e dívidas elevados no pagamento de juros, mas ao mesmo tempo expô-los a elevados riscos de refinanciamento e, por vezes, à exposição cambial. Esta situação acabaria por conduzir aos pedidos de ajuda internacional da Grécia, da Irlanda, de Portugal, do Chipre e, parcialmente, de Espanha (para o resgate dos bancos). Relativamente aos dois primeiros, o pedido de ajuda aconteceu em 2010, enquanto o de Portugal foi solicitado em abril de 2011.

A emergência desta crise motivou uma acesa discussão sobre várias questões relativas ao funcionamento dos mercados financeiros. Nelson et al. (2010) destacam o facto de os sucessivos governos gregos terem recorrido a derivados para ocultar o verdadeiro nível da dívida grega. Minescu (2010) refere que, após a emergência da crise financeira, o papel das agências de rating na prevenção de crises foi questionado; inclusive no âmbito da crise do subprime, o papel destas agências foi criticado por políticos e investidores, por estas terem falhado na sua identificação. Em consequência desta vaga de críticas, os reguladores têm-se mostrado 


\section{Egitania}

$s$ c i e $\Omega$ c i a

interessados em criar legislação sobre os conflitos de interesse, resultantes dos modelos de negócio usados por algumas agências de rating. Muitas outras questões de cariz financeiro, económico e político se colocaram e se virão a colocar, pois à data que elaboramos o presente trabalho a crise financeira global é uma história cuja conclusão não pode, ainda, ser escrita.

\section{CONTÁGIO FINANCEIRO E MECANISMOS DE TRANSMISSÃO}

O tema do contágio financeiro entre mercados bolsistas tem sido um dos mais debatidos na literatura financeira, principalmente desde a ocorrência do crash bolsista de 1987.

Calvo e Reinhart (1996) definem contágio financeiro como a transmissão de uma crise financeira de um determinado país a outro país, devido às ligações financeiras internacionais. Na mesma linha, Park e Song (2000) definem-no como a propagação de perturbações de um mercado a outro.

Partindo dos preços dos ativos, Bekaert et al. (2005) identificam esse contágio com o excesso de correlação relativamente aos fundamentos económicos. King e Wadhwani (1990), Calvo e Reinhart (1996) e Collins e Biekpe (2003), identificam-no através da intensificação das correlações entre os mercados financeiros, em períodos de turbulência ou de crise financeira.

Eichengreen e Rose (1998) e Glick e Rose (1999) apresentam uma definição mais abrangente, que inclui a transmissão de choques entre economias, através dos vários canais de transmissão. Masson (1999) e Van-Rijckeghem e Weder (2001) apresentam uma definição mais restritiva de contágio, considerando que o movimento simultâneo de variáveis económicas, em períodos de turbulência, é um sintoma da existência de contágio financeiro.

Lin et al. (1994) associam a definição de contágio financeiro à transmissão de volatilidade dos ativos financeiros de um determinado país em crise aos mercados financeiros de outros países, um facto comummente referido na literatura financeira. As crises podem, assim, ser identificadas com os períodos de ocorrência de volatilidades elevadas entre os mercados. Por outro lado, sendo a volatilidade dos preços dos ativos uma medida que está associada à incerteza do mercado, pode dizer-se que o contágio se refere à transmissão dessa incerteza entre os mercados financeiros.

Bae et al. (2003) associam os fenómenos de contágio à ocorrência de rendibilidades extremas, em vários mercados em simultâneo, por períodos de curta duração e com volatilidades elevadas.

Segundo Forbes e Rigobon (2000), a definição mais consensual de contágio financeiro é a de um aumento significativo no comovimento entre os mercados, após um choque sobre um determinado país ou grupo de países. Neste sentido, uma correlação elevada entre as rendibilidades de dois índices bolsistas, após a ocorrência de um choque, não implica forçosamente contágio, pois os mercados podem ser interdependentes. O que marca a ocorrência de contágio é o aumento significativo nas correlações entre os índices bolsistas. 


\section{Egitania}

$s$ c i e $\Omega$ c i a

Para caraterizar esta situação, estes autores utilizam a expressão contágio por deslocação (shiftcontagion).

Diversos estudos têm abordado os mecanismos de transmissão de crises entre economias e de exposição das economias a choques externos, associando o fenómeno aos canais de transmissão comercial, financeiro e puro. A junção dos canais comercial e financeiro constitui a chamada causa fundamental de contágio, sendo consequência das relações comerciais e financeiras entre as economias. O contágio puro ocorre quando a transmissão de choques não se explica totalmente através dos canais fundamentais, podendo ser consequência de alterações no comportamento dos investidores face ao risco, em resultado de quebras na sua confiança, de situações de aumento de aversão ao risco ou mesmo de pânico financeiro.

Dos canais fundamentais de contágio fazem parte os "choques" resultantes das relações comerciais e financeiras entre as economias, donde as designações de canal comercial e canal financeiro de transmissão ou propagação de crises.

Uma situação de contágio, através do canal comercial, ocorre quando há uma desvalorização da moeda de um país, que conduza a alterações nos fundamentos económicos de outros países com ele interrelacionados, através dos efeitos preço e rendimento. Os efeitos de contágio podem ser diretos e indiretos. Em ambos os casos estão ligados a desvalorizações da moeda de um país. Os primeiros estão ligados às consequências económicas sobre outros países, provocados por essa desvalorização monetária num país. Os segundos estão relacionados com a desvalorização da moeda de um país, que pressiona indiretamente outros países do mesmo mercado de exportação a também eles desvalorizarem as suas moedas, de modo a manterem o nível de competitividade, através do fator preço. Os estudos acerca do contágio, através da via canal comercial, inspiram-se no trabalho pioneiro de Nurkse (1944), que concluiu que a desvalorização da moeda de um país, ao contribuir para a descida dos preços de bens e serviços no mercado internacional, força outros países à desvalorização das respetivas moedas, para não perderem competitividade ao nível dos preços e para melhorarem o desempenho da sua balança comercial. Glick e Rose (1999) estudaram diversas crises cambiais, desde o colapso de Bretton Woods (1971) até à crise asiática de 1997, tendo concluído que as crises financeiras tendem a ter uma dimensão regional e que a sua propagação acontece no âmbito das relações comerciais com os países vizinhos.

Corsetti et al. (2000) recorreram à teoria dos jogos para analisar os efeitos da desvalorização de uma moeda nos níveis de bem-estar de outros países. De acordo com estes autores, se os atores de mercado acreditarem que a crise cambial poderá dar origem a um jogo que envolva desvalorizações competitivas, estes tentarão vender títulos que detenham noutras economias e reduzirão a concessão e a renovação de empréstimos, o que ampliará as consequências da desvalorização inicial.

De forma particularmente visível a partir da década de 1980, o canal financeiro de transmissão de contágio ganhou importância com a liberalização financeira e com o crescimento dos fluxos de capitais. Esta situação contribuiu para o aumento da integração dos mercados e criou condições propícias à transmissão de "choques" internacionais, cujo impacto depende do grau 


\section{Egitania}

$s$ c i e $\Omega$ c i a

de integração dos mercados financeiros. O canal financeiro compreende efeitos diretos e indiretos. Os primeiros derivam da reavaliação das decisões de investimento nos países vítimas do contágio financeiro. Os segundos resultam da atuação de investidores de outros países não envolvidos diretamente no "choque". Enquanto detentores de investimentos no país envolvido, reagem ao choque nesse mercado através de decisões de desinvestimento noutros países que apresentem idêntico perfil de risco.

Os estudos acerca do contágio através do canal financeiro têm-se preocupado, essencialmente, com dois aspetos: o papel do credor comum e o papel dos investidores institucionais. O primeiro está relacionado com o ajustamento do risco da carteira do investidor comum nos países envolvidos, direta ou indiretamente, no choque, o que contribui para a ampliação e a propagação do "choque" financeiro (Kaminsky e Reinhart, 2000; Van-Rijckeghem e Weder, 2001); o segundo resulta de alterações nas carteiras de investidores institucionais e na eventual liquidação de investimentos, quer no país onde o choque emergiu quer noutros países de idêntico perfil de risco (Goldfajn e Valdés, 1997). De acordo com Kaminsky et al. (2003), os referidos aspetos são elementos prévios à ocorrência de situações de contágio. A verificação do choque só ocorrerá se o elemento desencadeador não for antecipado. Este facto assume maior relevância no caso do credor comum que, ao ser surpreendido por uma crise, poderá não ter tempo para reajustar a sua carteira, o que limita os efeitos do choque. Se o choque for antecipado ou previsto, o investidor poderá limitar a sua exposição à economia em causa e a outras economias de idêntico perfil de risco.

A transmissão de contágio nem sempre encontra justificação na teoria económica, em especial em períodos de elevada turbulência (Eichengreen e Mody, 2000; Forbes, 2002). Os mecanismos não justificáveis com os fundamentos económicos são designados por contágio puro e resultam do comportamento dos investidores nos mercados financeiros, designadamente da imitação entre agentes (herding) e de problemas de informação. As questões relacionadas com as escolhas dos investidores em condições de incerteza foram determinantes para o desenvolvimento de uma nova teoria de finanças, a teoria de finanças comportamentais ${ }^{9}$, em resultado dos trabalhos pioneiros de Kahneman e Tversky (1974).

O efeito de contágio via herding é o resultado da imitação de comportamentos entre os investidores, que em certas circunstâncias abdicam de considerar a informação individual, que Ihes permite formar uma opinião acerca do binómio risco-rendibilidade, para assumirem decisões de investimento homogéneas, em linha com as de outros investidores, o que contribui para a ampliação e a transmissão de choques a outros mercados.

Entre as principais teorias explicativas dos comportamentos de imitação apresentadas na literatura consultada destacam-se as cascatas de informação, os problemas de agência e os

9 Esta teoria questionou o pressuposto de racionalidade do chamado homo economicus, que é uma espécie de alicerce da hipótese de eficiência informacional. De acordo com a teoria de finanças comportamentais, em vez do homo economicus, o investidor aproxima-se do homo reality, e é dotado de emoções e sentimentos, pelo que se revela incapaz de agir com plena racionalidade. As finanças comportamentais incorporam os aspetos comportamentais, de cariz psicológico e sociológico, no funcionamento dos mercados, fazendo com que estes não sejam informacionalmente eficientes. 


\section{Egitania}

s c i e $\cap$ c i a

problemas de informação (Chari e Kehoe, 2004; Chevalier e Ellison, 1999; Hirshleifer et al., 1994).

As cascatas de informação estão relacionadas com o processo de escolha perante alternativas de investimento, que num processo de procura e análise de informação, que implica custos, estes poderão ser minimizados se os investidores comunicarem entre si a informação que detêm, processo designado por cascata de informação. Quando um processo de tomada de decisão se inicia por simples imitação de comportamentos, com ignorância da sua informação individual, inicia-se a cascata, a qual, de acordo com Chari e Kehoe (2004), pode contribuir para situações de contágio. Se os investidores decidirem desfazer-se de ativos em determinado mercado, em consequência de um choque específico, a ocorrência de cascatas de informação pode levar a desinvestimentos noutros mercados com idêntico perfil de risco. Assim, mesmo em mercados sólidos e em que os respetivos agentes agem racionalmente, as cascatas de informação podem produzir efeitos de contágio penalizadores.

Os problemas de agência estão relacionados com a reputação dos profissionais de mercado e com o seu desempenho. Gestores de investimento e analistas de mercado imitam as decisões e as análises dos restantes agentes, em vez de confiarem nas suas competências pessoais, desconhecidas da generalidade do mercado, limitando-se a seguir o comportamento dos seus pares, o que dá origem a um fenómeno de comportamento imitativo (Chevalier e Ellison, 1999). Os critérios de desempenho são consequência das decisões de gestores de investimento, que desejam maximizar o seu desempenho, em termos relativos, condicionando as escolhas da sua carteira (Maug e Naik, 1996).

A questão da eficiência informacional, ou seja, da forma como a informação chega aos mercados, é outro fator que contribui para o herd behaviour. De acordo com Hirshleifer et al. (1994), a eficiência informacional justifica o facto de certos mercados merecerem grande atenção dos investidores, enquanto outros são ignorados.

\section{ANÁLISE REFLEXIVA}

À medida que o fenómeno da globalização financeira se foi aprofundando assistiu-se, em particular a partir da década de 1980, ao aumento da frequência com que episódios de crise financeira ocorreram, o que reforça a tese de Stiglitz (1999) de que a desregulamentação e a liberalização dos mercados não produziriam as consequências esperadas, em consequência de imperfeições de mercado. A livre entrada e saída de recursos financeiros deixou os mercados financeiros mais expostos e vulneráveis a situações de crise.

Em determinados momentos, as situações de turbulência e de stress são transversais à escala mundial, com consequências altamente nefastas para os investidores. A Crise Financeira Global é, porventura, o mais evidente exemplo das consequências decorrentes da grande proximidade entre os mercados. Esta crise apareceu como o resultado da pouca consistência do sistema financeiro internacional, fundado no dólar, na condição de moeda de reserva internacional, e no aprofundamento dos movimentos de globalização financeira, que deixaram as economias 


\section{Egitania}

$s$ c i e $\Omega$ c i a

vulneráveis a recorrentes crises financeiras, em particular desde o colapso dos acordos de Bretton Woods, em 1971.

A grave crise financeira iniciada em 2007, que ganhou dimensões sistémicas a partir de 2008, com repercussões nos mercados financeiros e nas taxas de crescimento do produto interno e do emprego, foi originada no centro do sistema económico, em concreto no espaço definido pela alta finança. Esta crise revelou-se diferente das ocorridas nos países periféricos, nas décadas de 1980 e 1990. Em primeiro lugar, porque emergiu do centro e não da periferia da economia. Em segundo lugar, porque não apenas evidenciou a instabilidade associada às economias desenvolvidas, sobretudo quando estas contam com sistemas financeiros altamente complexos e interligados, como também evidenciou as profundas falhas estruturais na regulação bancária. Adicionalmente, esta crise evidenciou diversos aspetos da arquitetura financeira internacional, até então ocultos, consubstanciados na construção de uma espécie de pirâmide de riscos, localizada no centro do sistema financeiro, que se viria a transformar em prejuízos astronómicos e em múltiplas situações de falência de grandes empresas financeiras.

O processo de globalização financeira criou as bases de um mercado financeiro global desregulado que, na procura permanente pela maximização do lucro, acabou por disseminar diversas inovações financeiras à escala global. Essas inovações criaram as condições propícias ao desenvolvimento da crise e à sua propagação por toda a economia mundial.

As situações vividas recentemente, em particular as que decorreram da crise global, marcadas pelo seu caráter sistémico e pelo seu elevado poder de contágio, facilitado pelos diversos mecanismos de transmissão, em especial os ligados ao chamado contágio puro, descrito por Eichengreen e Mody (2000) e Forbes (2002), entre outros, ajudaram a perceber que o processo de globalização financeira tem o seu lado menos positivo, com as implicações sociais e económicas das crises financeiras a revelarem-se muito mais dramáticas no contexto da globalização. Permitiram, igualmente, constatar que os mercados financeiros não são eficientes, não se auto regulam, nem se auto equilibram. Em consequência, parece-nos, pois, ter ficado demonstrada a necessidade de abrir espaço à regulação financeira, no plano internacional, através de limitação da alavancagem e de operações de securitização, que no entender de Getter et al. (2007) ajudam à disseminação do risco pelo mercado financeiro, mas igualmente da regulamentação dos hedge funds e dos paraísos fiscais, ou mesmo da adoção de mecanismos atenuadores da volatilidade dos mercados. Perante a evidente incapacidade das instituições internacionais na forma como lidaram com a crise, entendemos, igualmente, que esta reforçou a necessidade de uma coordenação global, de modo a evitar a ocorrência de episódios de crise de idêntica dimensão, dando lugar ao desenvolvimento de mecanismos que ajudem a salvaguardar as posições dos investidores e que minimizem as possibilidades de consequências nefastas para o sistema financeiro e para os países. Perante tais situações, decorre a necessidade de se repensar a governança do sistema económico financeiro, de modo a fazer frente às novas exigências e realidades geradas pela globalização e pela complexificação do Sistema Financeiro Internacional. 
Diversas soluções foram desenhadas no âmbito da recente crise financeira, com o propósito de tornar o sistema financeiro mais resiliente e menos vulnerável à ocorrência de crises. Nos EUA foi aprovada a chamada Lei Dodd-Frank, com o intuito de ajudar à reforma de Wall Street, promovendo a estabilidade do sistema financeiro, através de uma maior responsabilização e transparência do próprio sistema. Na União Europeia foram, igualmente, dados passos no mesmo sentido. Exemplo disso foi a implementação de uma nova arquitetura de supervisão, que envolveu a criação de um Comité Europeu do Risco Sistémico e do Sistema Europeu de Supervisão Financeira, de modo a monitorizar a estabilidade do conjunto do sistema financeiro e a garantir uma melhor supervisão do mesmo.

Parece-nos, contudo, que estas iniciativas poderão revelar-se meramente colaterais, na medida em que se centram no reforço da regulação e na supervisão do sistema financeiro. Acreditamos que a estabilização do sistema financeiro internacional poderá implicar a criação de uma instituição de âmbito internacional, ou eventualmente a reestruturação ou o fortalecimento das instituições atualmente existentes, que reúna condições para o estabelecimento de políticas a que o sistema financeiro no seu todo esteja vinculado.

\section{CONCLUSÃO}

A globalização e a multinacionalização de empresas foram acompanhadas por um processo de liberalização dos movimentos de capitais e de eliminação de barreiras impeditivas da livre circulação de fluxos monetários e financeiros. A globalização financeira traduz-se na integração dos mercados financeiros mundiais num mercado financeiro internacional. Foram três os principais fatores que deram origem à globalização financeira: os desenvolvimentos das TIC, a institucionalização dos mercados e a liberalização financeira.

O aumento significativo do IDE, sobretudo a partir da década de 1990, quer para os países desenvolvidos quer para os países em vias de desenvolvimento, mas também o reforço da importância dos mercados bolsistas mundiais, confirmada pela relação entre a capitalização bolsista e o PIB, são reflexos da globalização financeira.

O mercado bolsista dos EUA é, de forma destacada, o grande mercado mundial, por apresentar um nível de capitalização muito superior ao dos restantes mercados. O rácio entre o valor das ações negociadas e o PIB de cada país tem aumentado ao longo do tempo, sendo em muitos casos superior a um, o mesmo acontecendo em termos mundiais, o que confirma o peso dos mercados bolsistas no contexto internacional.

O desenvolvimento do processo de globalização financeira foi acompanhado por um aumento de volatilidade dos mercados e pela ocorrência de crises globais. A frequência com que têm ocorrido crises financeiras mostra que a desregulamentação, a liberalização e a livre entrada e saída de recursos financeiros deixou os mercados mais expostos e vulneráveis a situações de crise. 


\section{Egitania}

$s$ c i e $\Omega$ c i a

A história dos mercados bolsistas mundiais é uma história de crises. As quatro principais crises terão ocorrido em 1929, em 1987, em 2000 e em 2007/2008. Em todas estas crises houve um ponto em comum, traduzido no papel desempenhado pelos EUA, enquanto epicentro de todas elas.

No âmbito da literatura financeira internacional, o conceito de contágio ou de propagação de crises entre mercados, mas também os mecanismos de transmissão têm sido temas muito estudados, principalmente desde o crash financeiro de 1987. A maioria dos estudos associa o contágio financeiro à mudança nos padrões de correlação dos mercados financeiros. Nesta linha, Forbes e Rigobon (2000) associam situações de contágio entre os mercados a uma alteração significativa na relação linear.

As teorias clássicas identificam três tipos de canais de transmissão do contágio financeiro: o canal comercial, o canal financeiro e o do contágio puro. O binómio canal comercial e canal financeiro formam a causa fundamental de contágio, que está associada à existência das relações comerciais e financeiras entre as economias. O contágio puro está associado à transmissão de choques não explicadas pelos canais anteriores, sendo consequência da imitação de comportamentos entre os investidores e da verificação de imperfeições de mercado.

As consequências resultantes da crise financeira global, facilitadas pela liberalização financeira, pela complexificação financeira e pelos mecanismos facilitadores de transmissão de choques no sistema financeiro, levam a repensar os mecanismos de supervisão e de governação, de modo a limitar a ocorrência de episódios de idêntica dimensão.

\section{REFERÊNCIAS}

Bae, K., Karoly, G. e Stulz, R., (2003), “A New Approach to Measuring Financial Contagion”, the Review of Financial Studies, 16, PP. 717-763.

Banco de Portugal, (2008), Biblotema: A Crise do Subprime, Newsletter da BiblioteCA, Número 2, Setembro 2008, Lisboa.

Banco Mundial, (2013). World Bank Open Data. Disponível em htTP://DAtA. Worldbank.ORg/. Consultado em 2013.

Bekaert, G., Harvey, C. e NG, A., (2005), “Market integration and contagion”, Journal Of Business, 78, 1: 39-69.

Bekaert, G., Ehrmann, M., Fratzscher, M. e Mehl, A., (2011), "Global Crises and Equity Market Contagion. National Bureau of EECONOMIC REREARCH", WORKING Paper 17121. HTTP://WWW.NBS.RS/EXPORT/SITES/DEFAult/INTERnet/LAtiniCA/90/90_9/MICHAEL_EHRMANn_WP. PDF.CONSUltAdO EM 2012.

Belletante, B., (1996), Dictionnaire de la Bourse e des Marchés, Hatier.

Bhatia, A. (2007), "New Landscape, New Challenges: Structural Change and Regulation in the U.S. Financial Setor", IMF Working PAPER, 07/195.

Boyer, R., (1997), MONdialisation au dela des mythes, La DÉCOUVerte, PARIS.

Calvo, S. e Reinhart, C., (1996), "CApital flows to Latin America: is there eVidence Of CONtagions effects?”, Policy Research Working, PAPER 1619, THE WORLD BANK. 


\section{Eqgitania \\ $s$ c i e $\Omega$ c i a}

Chari, V. e Kehoe, P., (2004), "Financial Crisis as Herds: OVerturning the Critiques", Journal Of Economic TheOry, 119 , pp. 128 150.

Chesnals, F., (1998), A Mundialização Financeira, Xamã, São Paulo.

Chevalier, J. e Ellison, G., (1999), "Career Concerns of Mutual Fund Managers", Quarterly Journal Of Economics, 11 4, pp. 389. 432.

Claessens. S., Dell'Ariccia, G., Igan, D. e Laeven, L., (2010), "Lessons and Policy Implications from the Global financial Crisis”, IMF WORKING PAPER, NO. 10/44.

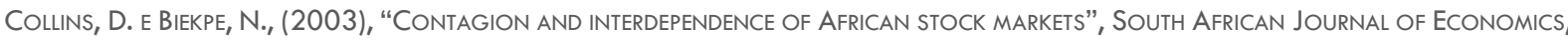
71, 1:181-194.

Corsetti, G., Pesenti, P., Roubini, N. e Tille, C., (2000), "Competitive Devaluations: A Welfare-Based Approach", Journal of INTERNATIONAL ECONOMICS, 51, PP. 217-41.

DeBroeck, M. e Guscina, A., (2011), "Government Debt Issuance in the Euro Area: The Impact of the Financial Crisis", IMF Working PAPER WP/11/21, JANUARY.

Dimartino, D. e Duca, J., (2007), "The rise and fall of subprime mortgages", Federal Reserve Bank of Dallas, Economic Letter, vol. 2 №. 11.

Eichengreen, B. e Mody, A., (2000), "What Explains Changing Spreads on Emerging Market Debt: Fundamentals or Market Sentiment?" In The EConomics of International Capital Flows, Ed. S. Edwards, University of Chicago Press.

Eichengreen, B. e Rose, A., (1998), "Contagious Currency Crisis: Channels of Conveyance." in Changes in Exchange Rates in Rapidiy Developing Countries: Theory, Practice, and Policy Issues, Ed. T. Ito e A. Krueger, University of Chicago Press.

Fabozzi, F., (1995), InVestment Management, Prentice-Hall.

Forbes, K. (2002), “Are Trade linkages Important Determinants of Country Vulnerability to Crises?" In Preventing CurRency CRises in Emerging Markets, Ed. S. EdWARds e J. Frankel, University Chicago Press.

Forbes, K. e Rigobon, R., (2000), “Contagion in Latin America: Definitions MeAsurement, and Policy Implications”, NBer Working PAPER 7885.

Galbraith, J., (2009), The Great Crash OF 1929, Mariner Books.

Getter, D., Jickling, M., Labonte, M. e Murphy, E., (2007), "Financial Crisis? The Liquidity Crunch of August 2007, Congressional Research Service", Report for Congress, Washington D.C.: Government Finance Division, 1-23.

Glick, R. e Rose, K., (1999), "Contagion and Trade: Why Are Currency Crises Regional?", Journal Of International Money and FINANCE, 18, PP. 603-617.

Goldfajn, I. e Valdés, R., (1997), “CAPital Flows and the TWin CRISes: The Role Of Liquidity.. Working Paper”, International Monetary FUND.

Gorton, G., (2009), "The Subprime Panic, Yale School of Management and NBeR”, European Financial Management, Vol. 15, No. $1,10-46$.

Helleiner, E., (1995), "Great Transformations: A Polanyan Perspetive on the Contemporary Global financial Order", Studies in Poltical EConomy, 48. Impact of the Financial Crisis, IMF Working Paper WP/1 1/21, JanUary 2011.

Hirshleifer, D., Subrahmanyam, A. e Titman, S., (1994), "Security Analysis and Trading Patterns when some Investors Receive INFORMATION BEFORE Others", JOURNAL OF FinANCE, 49, PP. 1665-98. 


\section{Egitania \\ s c i e $\Omega$ c i a}

Jansen, D. e DeVries, C., (1991), "On the Frequency of Large Stock Returns: Putting Booms and Busts into Perspetive”, Review of ECONOMICS AND STATISTICS, 73, PP. 18-24.

Kahneman, D. e TVersky, A., (1974), “Judgment Under UnCertaintY: Heuristics AND Biases”, SCIenCE, 185, p. $1124-1131$.

Kaminsky, G. e Reinhart, C., (2000), “ON CRISIS, Contagion, and Confusion”, Journal Of International EConomics, 51, pp. 145 -68.

Kaminsky, G., Reinhart, C. e VéGh, C., (2003), "The Unholy Trinity of Financial Contagion”, Journal Of Economic Perspetives, 17, PP. $51-74$.

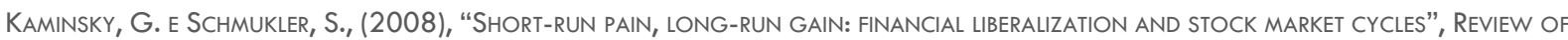
FINANCE, 1 2, 253-292.

KindleberGer, C., (2000), MANias, Panics And Crashes: A History of Financial Crisis, John Wiley \& Sons.

KINDLEBerger, C. E Aliber, R., (2005), MANIAS, PANICS, AND CRASHES, JOHn WILEY \& SONS, INC.

King, M. e Wadhwani, S., (1990), "Transmission of Volatility between Stock markets", Review of Financial Studies, 3(1), 5-33.

Kregel, A., (2008), “Minsky’s Cushions of Safety”, The levy Economics Institute of Bard College Public Policy Brief, No. 93 A.

Lin, W., ENGle, R. E Ito, T., (1994), "DO Bulls and Bears Move Across Borders? International Transmission of Stock Returns and VOLATILITY", REVIEW OF FINANCIAL StUdies, 7, PP. 507-38.

Lin, J. e Treichel, V., (2012), "The Unexpected Global financial Crisis Researching its Root Cause", World Bank. WPS5937. HTTP://WWW-WDS.WORLDBANK.ORG/SERVLET/WDS

CONTENTSERVER/ WDSP/IB/2012/01/09/000158349_20120109085942/RENDERED/PDF/W PS59 37.PDF. CONSULTADO EM 2012.

Malkiel, B., (1989), "Efficient Market Hypothesis in the New Palgrave”, Finance, New York: W.W. Norton.

Masson, P., (1999), "Contagion, Monsoonal Effects, Spillovers, and Jumps between Multiple Equilibria." in The Asian Financial Crisis; Causes, Contagion and Consequences, Ed. P.R. Agenor, M. Miller, D. Vines e A. Weber, Cambridge University Press.

McKinsey Global Institute, (2010), “Debt and Deleveraging: The Global Credit Bubble and its Economic Consequences”.

Minescu, A., (2010), "A Study on the Fallure of sovereign Credit Ratings", The Business Review Cambridge, ISSN 1553 - 5827, Vol. 16, DECEMBER 2010.

Modigliani, F. e Perotti, E., (1991). "The Rules of the Game and the Development of SeCurity Markets", In Pacific-Basin Capital Markets RESEARCH, VOL 2, AMSTERDAM-NORTH-HOLLAND.

Nelson, R., Belkin, P. e Mix, D., (2010), “GreeCe's Debt Crisis: OVervieW, Policy Responses, ANd Implications”, Congressional ResearCh SERVICE, 7-5700, WWW.CRS.GOV, R41 167, 27TH APRIL.

Nurkse, R. (1944), “International Currency Experience: Lessons of the Interwar Period”, League of Nations, Geneva.

Park, Y. e Song, C., (2000), "Financial Contagion in the East Asian Crisis: With Special Reference to the Republic of Korea", In: Claessens, S. and Forbes, K. (Eds.), International Financial Contagion, Massachusetts: Kluwer Academic Publishers.

Plihon, D., (2007), “A Globalização Financeira. Colóquio Pobreza, Dívida Externa e as Três Instituições Irmãs: FMI, Banco Mundial E OMC", FACULDADE DE ECONOMIA, UnIVERSIDADE DE CoIMBRA.

Purnanandam, A., (2009), "Originate-to-Distribute Model and the Subprime Mortgage Crisis, University of Michigan, Banco de Portugal, CONFERENCE: FinANCIAL INTERMEDIATION.

Putman, B. e Zimmer, S., (1987), "The Blackwell Guide to Wall Street”, Hardcover. Quarterly. 


\section{Egitania \\ s c i e $\Omega$ c i a}

Rappoport, P. e White, E., (1994), “WAs the Crash of 1929 Expected?”, The American Economic ReView, March.

Reinhart, C. e Rogoff, K. (2009), “The Aftermath Of the finAnCial Crisis”, NBER Working Paper 14656.

Rogoff, K. e Reinhart, C., (2010), Oito séCulos de delííos financeiros: desta Vez é diferente, PrinCeton University Press.

Shiller, R., (2006), IRRATIONAL EXuberanCE, BROAdWAY BoOKS: NeW York.

Sornette, D., (2004), "A Complex System View of Why Stock Markets Crash”, New Thesis, 01 (1): 5-18.

StiglitZ, J., (1999), "MORE InStRUMENTS AND BROADER GOALS: MOVING tOWARD tHE POST-WASHINGTON CONSENSUS", ReVISTA DE ECONOMIA POLÍTICA, N. 19, v. 1 (73).

Strange, S., (1990), "Finance, Information And Power", ReView of International Studies, 16.

VAn-RijCKeghem, C. E Weder, B., (2001), "SOurCes of Contagion: Is it Finance OR Trade?" Journal of International EConomics, 54, PP. 293-300.

Wigmore, B., (1985), The Crash and its Aftermath, Westport, Ct: Greenwood.

Wigmore, B., (1997), SeCurities MARKetS IN the 1980s, Hardcover.

Williams, R., (1993) “TeChnical Change: Political Options and Imperatives”, Government and Opposition, 28. 